\title{
GRAFTING METHOD OF FLUORINATED COMPOUNDS TO CELLULOSE AND CELLULOSE ACETATE: CHARACTERIZATION AND BIODEGRADATION STUDY
}

\author{
FATIMA EZAHRA TABAGHT, ${ }^{*}$ ABDERRAHMANE EL IDRISSI, ${ }^{*}$ MOHAMED AQIL,,$*$ \\ ALI ELBACHIRI, ${ }^{* * *}$ ABDESLAM TAHANI ${ }^{* * *}$ and ABDELKARIM MAAROUFI ${ }^{*}$ \\ "Laboratory of Applied Chemistry and Environment, Mohamed I University, \\ Faculty of Sciences, Oujda, Morocco \\ *** Materials Science and Nano-engineering, Mohammed VI Polytechnic University (UM6P), \\ Lot 660 Hay Moulay Rachid, Ben Guerir, Morocco \\ *** Laboratory of Physical Chemistry of Natural Resources and Environment, \\ Mohamed I University, Faculty of Sciences, Oujda, Morocco \\ ${ }^{* * * * *}$ Laboratory of Composite Materials, Mohamed V University, Faculty of Sciences, Rabat, Morocco \\ $\square$ Corresponding author: F. E. Tabaght, f.tabaght@ump.ac.ma
}

Received July 14, 2020

Cellulose (Cell) and cellulose acetate (CA) are attractive durable materials; they can acquire various properties through modification in order to obtain valuable industrial products. First, a series of novel fluorinated cellulose carbamate and fluorinated CA carbamate have been synthesized. The introduction of fluoro-groups onto cellulose and CA chain backbone was achieved by the one-pot grafting method using diisocyanate as a coupling agent, which can be considered as a green procedure. The compounds prepared were characterized by Fourier transform infrared spectroscopy (FTIR), nuclear magnetic resonance (NMR), X-ray diffractometry (XRD), thermogravimetric analysis (TGA) and differential thermogravimetry (DTG) measurements. The results obtained from these analytical techniques confirm that modification occurs successfully. Second, the solubility behavior and biodegradation process of these new fluorinated materials have been studied. The results show that these new materials exhibit better solubility compared to cellulose, but this solubility decreases compared to that of CA. The phenomenon of biodegradation was studied using two methods, the rate of biodegradability was determined. The results of this part show that the biodegradation of fluorinated materials decreases compared to that of the starting materials. These novel materials are biodegradable, can substitute currently used industrial non-biodegradable products and be promising agents for several uses, such as bioplastics, drug carriers, etc. A sustainable development and an increased use of green chemistry principles are among the essential objectives of this work.

Keywords: cellulose, cellulose acetate, carbamates of cellulose, fluorinated compounds, biodegradation process

\section{INTRODUCTION}

The use of natural renewable resources, such as cellulose and its derivatives, as reinforcing elements in bio-composites has gained considerable attention, as emphasized by numerous reviews. ${ }^{1-13}$ These biocomposites can be biodegradable or recyclable like thermoplastic matrices or incinerated to recover energy (combustion of thermosetting composites), compared to composites based on glass fibers. ${ }^{10}$ In addition, cellulose fibers possess several potential advantages, namely: (i) their low density, (ii) their bio-renewable character, (iii) their ubiquitous availability at low cost and in a variety of forms (wood, annual plants, agricultural residues, etc.) and (iv) their modest abrasivity, which ensures greater longevity of the processing tools. ${ }^{10}$ Cellulose fiber, which represents the major content of ligno-cellulosic biomass, is also inexpensive, biodegradable and has received a great deal of attention due to its physical properties and chemical reactivity. ${ }^{14}$ In addition, according to its molecular structure, cellulose is an active chemical due to the presence of three hydroxyl groups in each glucose unity, which are 
mainly responsible for this reactivity. This reactivity should not be simply regarded as being that of a tri-hydric alcohol that is similar in its chemistry to sugars having three hydroxyl groups, because cellulose is a fiber-forming and a high molar mass substance. However, cellulose has some inherent drawbacks, including poor solubility in common solvents, poor crease resistance, poor dimensional stability, lack of thermoplasticity, high hydrophilicity and lack of antimicrobial properties. To overcome such drawbacks, controlled physical and/or chemical modifications of the cellulose structure are necessary and these modifications can confer new properties (such as super-absorbency, superhydrophobicity, anti-adhesion, antimicrobial activity, compatibilization, etc.) to cellulose, without destroying its many desirable intrinsic properties. ${ }^{14,15}$ These modifications are also based on the exploitation of the hydroxy functions present at the surface of cellulose. ${ }^{15}$ Esterification, ${ }^{16-18}$ etherification, ${ }^{19,20}$ amidation, ${ }^{21}$ carbamation, ${ }^{22-25}$ nucleophilic substitution and click chemistry have been reported as techniques to modify the surface of cellulose. ${ }^{26}$

The carbamation, as an example, is a chemical modification of cellulose by an isocyanate group or blocked diisocyanate. The high and broad reactivity of such groups has been exploited using a coupling agent, and leading to a variety of applications, including in coatings, adhesives and cross-linking in the development of solid propellants. $^{26,27}$

Perfluorinated compounds (PFCs) are organic substances in which all of the hydrogens of the hydrocarbon backbones are substituted with fluorine atoms. The fluorine-carbon bonds are extremely stable, conferring very high thermal and chemical stability to these substances. ${ }^{28}$ They have a suite of unique properties, such as amphiphobicity and high chemical, biological and thermal stability. Taking into account these properties, PFCs are widely used in commercial and industrial applications as lubricants, surface protective agents and surfactants. ${ }^{29}$ They can be divided into the following groups: perfluorinated sulfonic acids, perfluorinated carboxylic acids, fluorotelomer alcohols, high-molecular weight fluoropolymers and low-molecular weight perfluoroalkanamides. ${ }^{28}$ The introduction of fluorine groups into organic molecules is of great interest for the development of pharmaceuticals, agrochemicals, and functional materials, since these groups enhance properties such as metabolic stability, lipophilicity and dipole moment. ${ }^{30}$ The chemical and thermal stability of a perfluoroalkyl moiety, in addition to its hydrophobic and lipophobic nature, leads to highly useful and enduring properties in surfactants and polymers into which the perfluoroalkyl moiety is incorporated. Polymer applications also include textile staining and soil repellents, as well as grease-proof, food-contact paper. $^{31}$ Furthermore, fluorinated organic compounds can also be applied as fluorosurfactants, which can lower the surface tension of water down to a value half of what can be reached by using hydrocarbon surfactants. More recently, fluorosurfactants have been used for the synthesis of mesoporous materials. ${ }^{32}$

For cellulose modification, a recent study using trifluoroacetic anhydride as a reagent to esterify the surface of cellulose fibers, was conducted in the gas and the liquid phase. ${ }^{33-36}$ Nystrom et al. ${ }^{37}$ reported the surface modification of cellulose fibers with a long perfluoro-alkyl chain, which was grafted either directly or through an intermediate layer of $\mathrm{OH}$-bearing polymers. More stable perfluorinated cellulose derivatives were prepared by esterifying the surface of cellulose fibers with two other perfluorinated reagents, viz., pentafluorobenzoyl chloride $(\mathrm{PFBz})^{38}$ and 3,3,3-trifluoropropanoyl chloride (TFP), ${ }^{39}$ under controlled heterogeneous conditions. Ly et $a l .{ }^{15}$ recently reported the grafting of the surface of two model cellulose fibers, Avicel (AV), and Whatman paper (WP), with two fluorine-bearing alkoxysilanes. ${ }^{40}$ The presence of fluorated groups at the cellulose surface gave rise to strongly hydrophobic and lipophobic properties. ${ }^{40-45}$

The main purposes of this work are the following: (i) preparing novel compounds through grafting of fluorinated compounds onto cellulose and CA chain backbone using coupling reactions - this synthesis procedure using a sustainable raw material occurs in one-pot in order to avoid residues and wastes; (ii) characterizing the molecular structure, using FTIR spectroscopy, NMR spectroscopy techniques, XRD, TGA and DTG; (iii) studying the effect of different solvents on the solubility behavior of the fluorinated compounds. Furthermore, the biodegradation phenomena of the obtained cellulose derivatives will be established using two methods. 


\section{EXPERIMENTAL \\ Materials}

Cellulose powder $\left(\mathrm{DP}_{\mathrm{w}} \approx 1402\right.$ and $\mathrm{M}_{\mathrm{w}} \approx 227200$ $\mathrm{g} / \mathrm{mol}$ ) was extracted from Esparto grass (Stipa tenacissima) from Eastern Morocco, following the procedure developed by El Idrissi et $a l .{ }^{46}$ It was dried in a vacuum oven at $90{ }^{\circ} \mathrm{C}$ for $48 \mathrm{~h}$ before use. Dibutyl tin dilaurate (DBTL 95\%) was obtained from Aldrich and used as a catalyst. Lithium chloride ( $\mathrm{LiCl}$ 98\%) was obtained from Riedsl-de Haën. N,Ndimethylacetamide (DMAc), (1,6)-hexamethylene diisocyanate (HDI 98\%) and dodecanethiol (RSH $\geq 98 \%$ ) were purchased from Sigma-Aldrich. The reagents 1,1,2,2,3,3,4,4,5,5,6,6,6-tridecafluorohexan-1ol $\quad\left(\mathrm{C}_{6} \mathrm{~F}_{13} \mathrm{OH}\right) \quad\left(\mathrm{P}_{1}\right), \quad 1,1,2,2,3,3,4,4,5,5,6,6,6-$ tridecafluorohexane-1-thiol $\quad\left(\mathrm{C}_{6} \mathrm{~F}_{13} \mathrm{SH}\right) \quad\left(\mathrm{P}_{2}\right) \quad$ and $1 \mathrm{H}, 1 \mathrm{H}, 2 \mathrm{H}, 2 \mathrm{H}$-perfluorooctanethiol $\quad\left(\mathrm{C}_{6} \mathrm{~F}_{13} \mathrm{C}_{2} \mathrm{H}_{4} \mathrm{SH}\right)$ $\left(\mathrm{P}_{3}\right)$ were provided by the Macromolecular Engineering and Architectures Laboratory Montpelier, France - and the other chemicals were of analytical grade and were also purchased from SigmaAldrich.

FTIR experiments were performed using a Shimadzu Fourier Transform Infrared spectrometer FTIR-8400S, using a $\mathrm{KBr}$ disc containing $2 \%$ finely ground samples. Twenty scans were taken of each sample and recorded from 4000 to $400 \mathrm{~cm}^{-1}$. The FTIR spectra were accumulated at a resolution of $4 \mathrm{~cm}^{-1}$.

The ${ }^{1} \mathrm{H}$ NMR spectra were recorded in the Scientific Research Technical Support Units (UATARS), National Center for Scientific and Technical Research (CRNST) (Rabat, Morocco) using a Bruker Spectrometer $(300 \mathrm{MHz})$. Deuterated dimethyl sulfoxide (DMSO) was used as a solvent. Tetramethylsilane (TMS) was used as an internal standard. All spectra were recorded with 16 scans and a pulse delay of 20 s.

We have used the ${ }^{1} \mathrm{H}$ NMR technique to estimate the degree of substitution (DS) of CA, fluorinated cellulose (Cell-HDI- $\mathrm{P}_{1}$, Cell-HDI- $\mathrm{P}_{2}$ and Cell-HDI- $\mathrm{P}_{3}$ ) and fluorinated CA (CA-HDI-P ${ }_{1}$, CA-HDI- $\mathrm{P}_{2}$ and CAHDI- $P_{3}$ ), using Equation $1,{ }^{47}$ and the results are summarized in Table 2:

$$
D S=\frac{n_{A U G} * I_{i}}{n_{i} * I_{A U G}}
$$

where $I_{i}$ : integration of the grafted group (i); $I_{\text {AUG }}$ : integration of the cellulose skeleton; $n_{\text {AUE }}$ and $n_{i}$ : number of protons in cellulose or CA $\left(n_{A V G}=7\right)$ and in corresponding grafted group, respectively.

$$
\begin{aligned}
& D S_{\text {Cell-HDI-P }}=\frac{7 I_{\mathrm{CH}_{2}}}{8 I_{A U G(\mathrm{Cell})}}=\frac{7 * 4.99}{8 * 4.19}=1.04 \\
& D S_{\text {Cell-HDI-P }}=\frac{7 I_{\text {NH }}}{1 I_{A U G(\mathrm{Cell})}}=\frac{7 * 2.01}{1 * 11.26}=1.25 \\
& D S_{\text {Cell-HDI-P }}=\frac{7 I_{C H 3}}{1 I_{A U G(\mathrm{Cell})}}=\frac{7 * 0.19}{1 * 1.36}=0.98
\end{aligned}
$$

$$
\begin{aligned}
& D S_{C A}=\frac{7 I_{C H 3}}{3 I_{A U G(C A)}}=\frac{7 * 34.53}{3 * 47.63} \approx 1.7 \\
& D S_{C A-\mathrm{HDI}_{-} \mathrm{P}_{1}}=\frac{7 I_{C H 2}}{4 I_{A U G(C A)}}=\frac{7 * 1.63}{4 * 3.04}=0.93 ; \quad \text { the }
\end{aligned}
$$

global DS of CA-HDI-P $\mathrm{P}_{1}$ is equal to $1.7+0.9 \approx 2.6$

$D S_{C A-\mathrm{HDI}-\mathrm{P}_{2}}=\frac{7 I_{C H 2}}{4 I_{A U G(C A)}}=\frac{7 * 1.44}{4 * 3.72}=0.7 ; \quad$ the global DS of CA-HDI-P $\mathrm{P}_{2}$ is equal to $1.7+0.7 \approx 2.4$

$D S_{C A-\mathrm{HDI}-\mathrm{P}_{3}}=\frac{7 I_{C H 2}}{4 I_{A U G(C A)}}=\frac{7 * 0.50}{4 * 1.27}=0.68$; the global DS of CA-HDI- $\mathrm{P}_{3}$ is equal to $1.7+0.7 \approx 2.4$

Thermal behavior was determined using a Thermogravimetric Analyzer T4 pan and the operation was carried out under nitrogen atmosphere (50 $\mathrm{mL} / \mathrm{min})$. The sample was heated from 25 to $700{ }^{\circ} \mathrm{C}$ at a heating rate of $15^{\circ} \mathrm{C} \mathrm{min}^{-1}$. The weight loss of the sample at different temperature was recorded.

The X-ray diffraction (XRD) was performed using a diffractometer system (Shimadzu XRD 6000) with $\mathrm{Cu}(\lambda=0.154 \AA)$. To estimate the crystal structure of Cell-HDI- $\mathrm{P}_{1}$, Cell-HDI-P $\mathrm{P}_{2}$, Cell-HDI- $\mathrm{P}_{3}$, CA, CA-HDI$\mathrm{P}_{1}$, CA-HDI- $\mathrm{P}_{2}$, CA-HDI- $\mathrm{P}_{3}$, the crystallinity index (CrI) was calculated using Equation 2 cited in the literature: ${ }^{48}$

$$
\operatorname{CrI}(\%)=\frac{I_{002}-I_{a m}}{I_{002}} * 100
$$

where $\mathrm{I}_{002}$ is the maximum intensity (in arbitrary units) of the 002 lattice diffraction and $\mathrm{I}_{\mathrm{am}}$ is the intensity of diffraction in the same units at $2 \theta=18^{\circ}$.

\section{Methods}

Synthesis of fluorinated cellulose carbamate (CellHDI-P , Cell-HDI-P $_{2}$ and Cell-HDI-P ${ }_{3}$ )

Firstly, a blocked isocyanate (precursor) was synthesized by a simple reaction between alcohol or thiol and diisocyanate groups. In a three-necked roundbottom flask equipped with a funnel, a thermometer, a magnetic stirrer and a reflux condenser, $0.86 \mathrm{mmol}$ of 1,6-HDI was introduced and an equal molar of $\mathrm{C}_{6} \mathrm{~F}_{13} \mathrm{OH}$ with a relative amount of DBTL as a catalyst was placed in the funnel and added dropwise to the reaction mixture. The system was kept under stirring in nitrogen atmosphere at $80{ }^{\circ} \mathrm{C}$ for $3 \mathrm{~h}$. At the end, the blocked isocyanate was formed with a high yield. The reaction was followed by FTIR analysis and we noted the presence of an absorbance band at $2270 \mathrm{~cm}^{-1}$ associated with the NCO group in excess. Without insulating the blocked isocyanate precursor, the cellulose solution already prepared according to El Idrissi et al $^{46}(0.07 \mathrm{~g})$ was added to the mixture. This addition reaction was catalyzed by DBTL and kept under stirring at $80^{\circ} \mathrm{C}$ for $3 \mathrm{~h}$ in nitrogen atmosphere 
until all NCO groups were reacted, and their absorption band in the FTIR spectrum $\left(2270 \mathrm{~cm}^{-1}\right)$ disappeared. Then, a characteristic band corresponding to the carbamate formed appeared. The resulting product (Cell-HDI-P ${ }_{1}$ ) was isolated by filtration using a membrane filter. After precipitation in a mixture of methanol/water (1/3), the resulting product was washed with distilled water, methanol and dried under vacuum at $80{ }^{\circ} \mathrm{C} .{ }^{49}$ The fluorinated celluloses (CellHDI- $\mathrm{P}_{2}$ and Cell-HDI- $\mathrm{P}_{3}$ ) were synthesized following the same treatment. The fluorinated cellulose carbamates obtained were characterized by ${ }^{1} \mathrm{H}-\mathrm{NMR}$ and ${ }^{13} \mathrm{C}-\mathrm{NMR}$ techniques. An example of $\mathrm{NMR}$ spectrum is given in Figure 2. The NMR chemical shifts of the prepared derivatives (Cell-HDI-P $\mathrm{P}_{\mathrm{i}} \mathrm{i}=1,2$, 3) are reported below.

Cell-HDI- ${ }_{1}:{ }^{1} \mathrm{H}-\mathrm{NMR}\left(300 \mathrm{MHz}, \mathrm{DMSO}, 25{ }^{\circ} \mathrm{C}\right.$, ppm): $\delta 0.96-1.77$ (-HN-( $\left.\left.\mathrm{CH}_{2}\right)-\left(\mathrm{CH}_{2}\right)_{4}-\left(\mathrm{CH}_{2}\right)-\mathrm{NH}-\right)$; $2.98\left(-\mathrm{HN}-\mathrm{CH}_{2}-\left(\mathrm{CH}_{2}\right)_{4}-\mathrm{CH}_{2}-\mathrm{NH}-\right)$; 3.00-4.85 (-CH- of $\left.\mathrm{AUG}_{\mathrm{Cell}}\right) ; 4.25\left(-\mathrm{CH}_{2-}\right.$ of $\left.\mathrm{AUG}_{\mathrm{Cell}}\right)$ and $5.78(-\mathrm{NH}-)$. ${ }^{13} \mathrm{C}-\mathrm{NMR}$ (300 MHz, DMSO, $25{ }^{\circ} \mathrm{C}$, ppm) $\delta: 22.1$ ($\left.\mathrm{HN}-\mathrm{CH}_{2}-\left(\mathrm{CH}_{2}\right)_{4}-\mathrm{CH}_{2}-\mathrm{NH}-\right) ; 40.95\left(-\mathrm{HN}-\mathrm{CH}_{2}-\left(\mathrm{CH}_{2}\right)_{4}-\right.$ $\left.\underline{\mathrm{CH}}_{2}-\mathrm{NH}-\right) ; 62.13-75.05\left(\mathrm{CH}\right.$ of $\left.\mathrm{AUG}_{\mathrm{Cell}}\right) ; 62.13\left(\mathrm{CH}_{2}\right.$ of $\left.\mathrm{AUG}_{\mathrm{Cell}}\right) ; 113.80-128.74 \quad\left(-\mathrm{S}-\left(\mathrm{CF}_{2}\right)_{\underline{5}}-\mathrm{CF}_{3}\right)$ and 156.23 (OOC-HN-( $\left.\left.\underline{\mathrm{CH}}_{2}\right)_{6}-\mathrm{NH}-\mathrm{COO}\right)$.

Cell-HDI-P $\mathrm{P}_{2}:{ }^{1} \mathrm{H}-\mathrm{NMR}\left(300 \mathrm{MHz}, \mathrm{DMSO}, 25^{\circ} \mathrm{C}\right.$, ppm): $\delta$ 1.07-1.67 (-HN-CH $\left.2-\left(\mathrm{CH}_{2}\right)_{4}-\mathrm{CH}_{2}-\mathrm{NH}-\right) ; 2.95$ $\left(-\mathrm{HN}-\mathrm{CH}_{2}-\left(\mathrm{CH}_{2}\right)_{4}-\mathrm{CH}_{2}-\mathrm{NH}-\right) ; 3.04-4.78$ (-CH- of $\left.\mathrm{AUG}_{\mathrm{Cell}}\right) ; 4.47\left(-\mathrm{CH}_{2}-\right.$ of $\left.\mathrm{AUG}_{\mathrm{Cell}}\right) ; 5.78$ (-NH-COO-) and 7.78 (-NH-COS-). ${ }^{13} \mathrm{C}-\mathrm{NMR}(300 \mathrm{MHz}$, DMSO, $25^{\circ} \mathrm{C}$, ppm) $\delta: 25.71\left(-\mathrm{HN}-\mathrm{CH}_{2}-\left(\mathrm{CH}_{2}\right)_{3}-\left(\mathrm{CH}_{2}\right)_{2}-\mathrm{NH}-\right)$; $31.04\left(-\mathrm{HN}-\left(\mathrm{CH}_{2}\right)_{4}-\mathrm{CH}_{2}-\mathrm{CH}_{2}-\mathrm{NH}-\right) ; 40.65\left(-\mathrm{HN}-\mathrm{CH}_{2}-\right.$ $\left.\left(\mathrm{CH}_{2}\right)_{4}-\mathrm{CH}_{2}-\mathrm{NH}-\right) ; 62.81-81.06$ (-CH- of $\left.\mathrm{AUG}_{\mathrm{Cell}}\right)$; $64.16\left(-\mathrm{CH}_{2^{-}}\right.$of $\left.\mathrm{AUG}_{\mathrm{Cell}}\right) ; 104.19-128.37\left(-\mathrm{S}-\left(\mathrm{CF}_{2}\right)_{4}-\right.$ $\left.\mathrm{CF}_{3}\right) ; 150.22$ (-OOC-HN-) and 160.51 (-NH-COS-).

Cell-HDI-P ${ }_{3}:{ }^{1} \mathrm{H}-\mathrm{NMR}\left(300 \mathrm{MHz}, \mathrm{DMSO}, 25{ }^{\circ} \mathrm{C}\right.$, ppm): $\delta$ 0.98-1.81 (-HN-CH $\left.-\left(\mathrm{CH}_{2}\right)_{4}-\mathrm{CH}_{2}-\mathrm{NH}-\right) ; 2.01$ $\left(-\mathrm{S}-\mathrm{CH}_{2}-\mathrm{CH}_{2}-\mathrm{CF}_{2}-\right) ; 2.95\left(-\mathrm{HN}-\mathrm{CH}_{2}-\left(\mathrm{CH}_{2}\right)_{4}-\mathrm{CH}_{2}-\mathrm{NH}-\right.$ ); $3.09\left(-\mathrm{S}-\underline{\mathrm{CH}}_{2}-\mathrm{CH}_{2}-\mathrm{CF}_{2}-\right)$; 3.18-4.75 (-CH- of $\left.\mathrm{AUG}_{\mathrm{Cell}}\right) ; 4.27\left(-\mathrm{CH}_{2}\right.$ - of $\left.\mathrm{AUG}_{\mathrm{Cell}}\right) ; 5.78$ (-NH-COO-) and 8.24 (-NH-COS-). ${ }^{13} \mathrm{C}-\mathrm{NMR}$ (300 MHz, DMSO, $\left.25^{\circ} \mathrm{C}, \mathrm{ppm}\right) \delta$ : $18.12\left(-\mathrm{S}-\mathrm{CH}_{2}-\mathrm{CH}_{2}-\mathrm{CF}_{2}-\right) ; 27.06$ (-HN$\left.\mathrm{CH}_{2}-\left(\underline{\mathrm{CH}}_{2}\right)_{3}-\left(\mathrm{CH}_{2}\right)_{2}-\mathrm{NH}-\right) ; 28.71 \quad\left(-\mathrm{HN}-\left(\underline{\mathrm{CH}}_{2}\right)_{4}-\mathrm{CH}_{2}-\right.$ $\left.\mathrm{CH}_{2}-\mathrm{NH}-\right) ; 31.04$ (-S-CH$\left.-\mathrm{CH}_{2}-\mathrm{CF}_{2}^{-}\right) ; 40.18$ (-HN$\left.\mathrm{CH}_{2}-\left(\mathrm{CH}_{2}\right)_{4}-\mathrm{CH}_{2}-\mathrm{NH}-\right) ; \quad 59.80-83.38 \quad$ (-CH- of $\left.\mathrm{AUG}_{\mathrm{Cell}}\right) ; 62.81\left(-\mathrm{CH}_{2^{-}}\right.$of $\left.\mathrm{AUG}_{\mathrm{Cell}}\right)$; 101.86-121.46 ($\left.\left(\mathrm{CH}_{2}\right)_{2}-\left(\underline{\mathrm{CF}}_{2}\right)_{5}-\mathrm{CF}_{3}\right) ; 150.22$ (-O드-HN-) and 161.19 ($\mathrm{NH}-\mathrm{COS}-$ ).

\section{Synthesis of fluorinated CA carbamates (CA-HDI-P ${ }_{1}$, $\mathrm{CA}-\mathrm{HDI}-\mathrm{P}_{2}$ and $\mathrm{CA}-\mathrm{HDI}-\mathrm{P}_{3}$ )}

In a three-necked round-bottom flask equipped with a funnel, a thermometer, a magnetic stirrer and a reflux condenser, an amount of 1,6-HDI (0.57 mmol) was introduced, then an equal molar of $\mathrm{C}_{6} \mathrm{~F}_{13} \mathrm{OH}\left(\mathrm{P}_{1}\right)$ with a relative amount of DBTL as a catalyst was placed in the funnel and added dropwise to the reaction mixture. The system was maintained at $80{ }^{\circ} \mathrm{C}$ for $3 \mathrm{~h}$ under nitrogen atmosphere, the progress of the reaction was followed by FTIR analysis. We noted the presence of an absorbance band at $2270 \mathrm{~cm}^{-1}$ associated to the NCO group, showing that a free isocyanate precursor is formed. Without insulating the blocked isocyanate, the cellulose acetate solution already prepared according to the method described in the literature by Doyle and Pethrick ${ }^{50}$ (in DMSO - DS = 1.7) was added. This addition reaction was catalyzed by DBTL and kept under stirring at $80{ }^{\circ} \mathrm{C}$ for $3 \mathrm{~h}$ in nitrogen atmosphere until all NCO groups were reacted, and their absorption band in the FTIR spectrum $\left(2270 \mathrm{~cm}^{-}\right.$ $\left.{ }^{1}\right)$ disappeared. Then, a characteristic band corresponding to the carbamate formed appeared. The resulting product $\left(\mathrm{CA}-\mathrm{HDI}-\mathrm{P}_{1}\right)$ was precipitated in methanol, filtered and washed successively with distilled water, methanol and dried in an oven at $60{ }^{\circ} \mathrm{C}$ for $24 \mathrm{~h}$.

The fluorinated CAs (CA-HDI- $\mathrm{P}_{2}$ and CA-HDI-P $_{3}$ were also synthesized and isolated using the same procedure as above $\left(\left(\mathrm{C}_{6} \mathrm{~F}_{13} \mathrm{SH}\right)\left(\mathrm{P}_{2}\right)\right.$, $\left.\left(\mathrm{C}_{6} \mathrm{~F}_{13} \mathrm{C}_{2} \mathrm{H}_{4} \mathrm{SH}\right)\left(\mathrm{P}_{3}\right)\right)$. They were also characterized by ${ }^{1} \mathrm{H}-\mathrm{NMR}$ and ${ }^{13} \mathrm{C}-\mathrm{NMR}$ techniques. An example of NMR spectrum is given in Figure 2. The NMR chemical shifts of the prepared derivatives (CA-HDI-P $\mathrm{i}=1,2,3)$ are reported below.

CA-HDI-P ${ }_{1}:{ }^{1} \mathrm{H}-\mathrm{NMR}\left(300 \mathrm{MHz}, \mathrm{DMSO}, 25{ }^{\circ} \mathrm{C}\right.$, ppm): $\delta 1.24\left(-\mathrm{HN}-\left(\mathrm{CH}_{2}\right)_{2}-\left(\mathrm{CH}_{2}\right)_{2}-\left(\mathrm{CH}_{2}\right)_{2}-\mathrm{NH}-\right) ; 1.95$ (-HN-CH $\left.2-\mathrm{CH}_{2}-\left(\mathrm{CH}_{2}\right)_{2}-\mathrm{CH}_{2}-\mathrm{CH}_{2}-\mathrm{NH}-\right) ; 2.07$ (-OC$\mathrm{CH}_{3}$ - of CA); 2.98 (- $\left.\mathrm{HN}-\underline{\mathrm{CH}}_{2}-\left(\underline{\mathrm{CH}}_{2}\right)_{4}-\underline{\mathrm{CH}}_{2}-\mathrm{NH}-\right) ; 3.52-$ $4.90\left(-\mathrm{CH}-\right.$ of $\left.\mathrm{AUG}_{\mathrm{Cell}}\right) ; 4.24\left(-\mathrm{CH}_{2-}\right.$ of $\left.\mathrm{AUG}_{\mathrm{Cell}}\right)$ and 7.21 (-NH-). ${ }^{13} \mathrm{C}-\mathrm{NMR}$ (300 MHz, DMSO, $25{ }^{\circ} \mathrm{C}$, ppm) $\delta: 22.40\left(\mathrm{OC}-\mathrm{CH}_{3}\right.$ of $\left.\mathrm{CA}\right) ; 27.06\left(-\mathrm{HN}_{-}-\mathrm{CH}_{2}-\right.$ $\left.\left(\mathrm{CH}_{2}\right)_{4}-\mathrm{CH}_{2}-\mathrm{NH}-\right) ; 40.28$ (-HN- $\left.\mathrm{CH}_{2}-\left(\mathrm{CH}_{2}\right)_{4}-\mathrm{CH}_{2}-\mathrm{NH}-\right)$; 58.53-78.73 ( $\mathrm{CH}$ of $\left.\mathrm{AUG}_{\mathrm{Cell}}\right) ; 62.81\left(\mathrm{CH}_{2}\right.$ of $\left.\mathrm{AUG}_{\mathrm{Cell}}\right)$; 100.88-120.87 (-O- $\left.\left(\mathrm{CF}_{2}\right)_{5}-\mathrm{CF}_{3}\right) ; 156.83$ (OOC-HN$\left.\left(\mathrm{CH}_{2}\right)_{6}-\mathrm{NH}-\mathrm{COO}\right)$ and $170.12\left(\underline{\mathrm{OC}}-\mathrm{CH}_{3}\right.$ of $\left.\mathrm{CA}\right)$.

CA-HDI-P $:{ }^{1} \mathrm{H}-\mathrm{NMR}\left(300 \mathrm{MHz}, \mathrm{DMSO}, 25{ }^{\circ} \mathrm{C}\right.$, ppm): $\delta 1.24\left(-\mathrm{HN}-\left(\mathrm{CH}_{2}\right)_{2}-\left(\mathrm{CH}_{2}\right)_{2}-\left(\mathrm{CH}_{2}\right)_{2}-\mathrm{NH}-\right) ; 1.95$ (-HN-CH $\left.2-\mathrm{CH}_{2}-\left(\mathrm{CH}_{2}\right)_{2}-\mathrm{CH}_{2}-\mathrm{CH}_{2}-\mathrm{NH}-\right) ; 2.07$ (-OC$\mathrm{CH}_{3}$ - of CA); 2.95 (- $\left.\mathrm{HN}-\underline{\mathrm{CH}}_{2}-\left(\mathrm{CH}_{2}\right)_{4}-\mathrm{CH}_{2}-\mathrm{NH}-\right) ; 3.09$ $4.80\left(-\mathrm{CH}-\right.$ of $\left.\mathrm{AUG}_{\mathrm{Cell}}\right) ; 4.55\left(-\mathrm{CH}_{2}-\right.$ of $\left.\mathrm{AUG}_{\mathrm{Cell}}\right) ; 6.30$ (-NH-COO-) and 7.74 (- $\underline{\mathrm{NH}}-\mathrm{COS}-)$. ${ }^{13} \mathrm{C}-\mathrm{NMR}(300$ $\mathrm{MHz}, \mathrm{DMSO}, 25^{\circ} \mathrm{C}$, ppm) $\delta: 20.08\left(\mathrm{OC}-\underline{\mathrm{CH}}_{3}\right.$ of CA); $27.06\left(-\mathrm{HN}-\mathrm{CH}_{2}-\left(\mathrm{CH}_{2}\right)_{3}-\left(\mathrm{CH}_{2}\right)_{2}-\mathrm{NH}-\right) ; 32.32$ (-HN$\left.\left(\mathrm{CH}_{2}\right)_{4}-\mathrm{CH}_{2}-\mathrm{CH}_{2}-\mathrm{NH}-\right) ; 39.60\left(-\mathrm{HN}-\mathrm{CH}_{2}-\left(\mathrm{CH}_{2}\right)_{4}-\mathrm{CH}_{2}-\right.$ $\mathrm{NH}-)$; 59.50-75.05 (-CH- of $\left.\mathrm{AUG}_{\mathrm{Cell}}\right) ; 63.11\left(-\mathrm{CH}_{2-}\right.$ of $\left.\mathrm{AUG}_{\mathrm{Cell}}\right)$; 104.19-118.76 (-S- $\left.\left(\underline{\mathrm{CF}}_{2}\right)_{4}-\mathrm{CF}_{3}\right) ; 155.86$ (OOC-HN-); 169.75 (-NH-COS-) and 174.71 ( $\underline{\text { OC-CH }}$ of $\mathrm{CA}$ )

CA-HDI-P $:{ }^{1} \mathrm{H}-\mathrm{NMR}\left(300 \mathrm{MHz}, \mathrm{DMSO}, 25{ }^{\circ} \mathrm{C}\right.$, ppm): $\delta 1.24\left(-\mathrm{HN}-\left(\mathrm{CH}_{2}\right)_{2}-\left(\mathrm{CH}_{2}\right)_{2}-\left(\mathrm{CH}_{2}\right)_{2}-\mathrm{NH}-\right) ; 1.93$ $\left(-\mathrm{HN}-\mathrm{CH}_{2}-\mathrm{CH}_{2}-\left(\mathrm{CH}_{2}\right)_{2}-\mathrm{CH}_{2}-\mathrm{NH}-\right) ; 2.05\left(-\mathrm{OC}-\mathrm{CH}_{3}-\right.$ of $\mathrm{CA}) ; 2.50\left(-\mathrm{S}-\mathrm{CH}_{2}-\mathrm{CH}_{2}-\mathrm{CF}_{2}^{-}\right) ; 2.77\left(-\mathrm{HN}-\mathrm{CH}_{2}-\left(\mathrm{CH}_{2}\right)_{4}-\right.$ $\left.\mathrm{CH}_{2}-\mathrm{NH}-\right) ; 2.95$ (-S- $\left.\mathrm{CH}_{2}-\mathrm{CH}_{2}-\mathrm{CF}_{2}-\right) ; 3.05-5.29$ (-CHof $\left.\mathrm{AUG}_{\mathrm{CA}}\right) ; 4.53\left(-\mathrm{CH}_{2}-\right.$ of $\left.\mathrm{AUG}_{\mathrm{Cell}}\right) ; 5.76$ (-NH-COO) and 8.25 (-NH-COS-). ${ }^{13} \mathrm{C}-\mathrm{NMR}(300 \mathrm{MHz}$, DMSO, $25{ }^{\circ} \mathrm{C}$, ppm) $\delta: 17.17\left(-\mathrm{S}-\underline{\mathrm{CH}}_{2}-\mathrm{CH}_{2}-\mathrm{CF}_{2}{ }^{-}\right) ; 24.06$ (OC$\underline{\mathrm{CH}}_{3}$ of CA); 25.71 (-HN-CH$\left.-\left(\mathrm{CH}_{2}\right)_{3}-\left(\mathrm{CH}_{2}\right)_{2}-\mathrm{NH}-\right)$; 28.71 (-HN- $\left.\left(\mathrm{CH}_{2}\right)_{4}-\mathrm{CH}_{2}-\mathrm{CH}_{2}-\mathrm{NH}-\right) ; 33.37$ (-S-CH${ }_{2}^{-}$ 
$\left.\mathrm{CH}_{2}-\mathrm{CF}_{2}-\right) ; 40.95$ (- $\left.\mathrm{HN}-\mathrm{CH}_{2}-\left(\mathrm{CH}_{2}\right)_{4}-\mathrm{CH}_{2}-\mathrm{NH}-\right) ; 61.83-$ $79 . \overline{7} 1\left(-\mathrm{CH}-\right.$ of $\left.\mathrm{AUG}_{\mathrm{CA}}\right) ; 65.14\left(-\mathrm{CH}_{2}-\right.$ of $\left.\mathrm{AUG}_{\mathrm{Cell}}\right)$; 101.26-120.11 (- $\left.\mathrm{CH}_{2}-\left(\mathrm{CF}_{2}\right)_{5}-\mathrm{CF}_{3}\right) ; 156.83$ (-OOC-HN); 168.77 (-NH-COS-) and 170.12 ( $\underline{\mathrm{OC}}-\mathrm{CH}_{3}$ of CA).

\section{Solubility study}

Some dissolution tests of fluorinated cellulose carbamates (Cell-HDI- $\mathrm{P}_{1}$, Cell-HDI- $\mathrm{P}_{2}$ and Cell-HDI$\mathrm{P}_{3}$ ) and fluorinated CA carbamates (CA-HDI-P 1 , CAHDI- $\mathrm{P}_{2}$ and CA-HDI- $\mathrm{P}_{3}$ ) were carried out. In the first step, powder samples were placed in a small weighing bottle and dried in a vacuum oven at $70{ }^{\circ} \mathrm{C}$. In the second step, $0.1 \mathrm{~mL}$ of an adequate solvent was added to the dried samples $(1 \mathrm{mg})$. The bottle was placed at $120{ }^{\circ} \mathrm{C}$. The mixture was kept under stirring until the powder disappeared (visual monitoring) and transparent solutions were obtained. The results are reported in Table 2.

\section{Biodegradability}

There are several different methods and techniques to determine the degradability of plastic materials. In this work, we have focused on visual observations and the quantitative determination of microbial growth when fluorinated compounds are submitted to biodegradation and used as a carbon source. This test was carried out in two steps. The first one was based on visual observation of the crossroads of the microorganisms (solid medium). The second test was based on the calculation of the biomass $(\mathrm{g})$ resulting from the biodegradation phenomena (liquid medium); then, this test was reinforced by the biodegradability investigation following the standard test method ISO 14851.

Biodegradation under aerobic solid conditions: This test method has been standardized and adopted basically in the same form by the American Society for Testing and Materials (ASTM G21-70, G22-76, G2975), by the French Association for Normalization (AFNOR $X$ 41-514-81 and X41-517-69), by the German Institute of Standardization (DIN 53739) and by the International Organization for Standardization (ISO 846). ${ }^{51}$ The tested samples were placed on the surface of a mineral salt agar $\left(\mathrm{M}_{\mathrm{S}}\right)$, which is composed of monopotassium phosphate $\left(\mathrm{KH}_{2} \mathrm{PO}_{4}: 0.7 \mathrm{~g}\right)$, potassium hydrogen phosphate $\left(\mathrm{K}_{2} \mathrm{HPO}_{4}: 0.7 \mathrm{~g}\right)$, magnesium sulfate heptahydrate $\left(\mathrm{MgSO}_{4} / 7 \mathrm{H}_{2} \mathrm{O}: 0.7 \mathrm{~g}\right)$, ammonium nitrate $\left(\mathrm{NH}_{4} \mathrm{NO}_{3}: 1 \mathrm{~g}\right)$, sodium chloride $(\mathrm{NaCl}: 0.005 \mathrm{~g})$, ferrous sulfate heptahydrate $\left(\mathrm{FeSO}_{4} / 7 \mathrm{H}_{2} \mathrm{O}\right.$ : $\left.0.002 \mathrm{~g}\right)$, zinc sulfate heptahydrate $\left(\mathrm{ZnSO}_{4} / 7 \mathrm{H}_{2} \mathrm{O}: 0.002 \mathrm{~g}\right)$ and manganese sulfate heptahydrate $\left(\mathrm{MnSO}_{4} / 7 \mathrm{H}_{2} \mathrm{O}: 0.001 \mathrm{~g}\right)$ dissolved in sufficient distilled water to make up $1000 \mathrm{~mL}$ with agar (autoclaving at $121{ }^{\circ} \mathrm{C}$ for $20 \mathrm{~min}$ and the $\mathrm{pH}$ was between 6.0 and 6.5 ) in a Petri dish containing no additional carbon source. The material tested and the agar medium were sprayed with standardized mixed inoculums of lixivia. Petri dishes were incubated at a constant temperature $\left(25^{\circ} \mathrm{C}\right)$ during 21 to 28 days. The tested material was then subjected to visual assessment.

Biodegradation under aerobic liquid conditions: The assessment of biodegradability has been performed following the standard test method ISO $14851 .{ }^{52}$ Glass flasks with a $600 \mathrm{~mL}$ capacity were used as test vessels. The flasks were filled till a final $400 \mathrm{~mL}$ volume and kept closed with glass caps. The test liquid medium was the "standard test medium" described in ISO 14851 (Determination of the ultimate aerobic biodegradability of plastic materials in an aqueous medium-method by measuring the oxygen demand in a closed respirometer), based on the following solutions:

- Solution A: $\mathrm{KH}_{2} \mathrm{PO}_{4}(8.5 \mathrm{~g} / \mathrm{L}), \mathrm{K}_{2} \mathrm{HPO}_{4}(21.75$ $\mathrm{g} / \mathrm{L}), \mathrm{Na}_{2} \mathrm{HPO}_{4} .2 \mathrm{H}_{2} \mathrm{O}(33.4 \mathrm{~g} / \mathrm{L}), \mathrm{NH}_{4} \mathrm{Cl}(0.5 \mathrm{~g} / \mathrm{L})$;

- Solution B: $\mathrm{MgSO}_{4} .7 \mathrm{H}_{2} \mathrm{O}(22.5 \mathrm{~g} / \mathrm{L})$;

- Solution C: $\mathrm{CaCl}_{2} \cdot 2 \mathrm{H}_{2} \mathrm{O}(36.4 \mathrm{~g} / \mathrm{L})$;

- Solution D: $\mathrm{FeCl}_{3} \cdot 6 \mathrm{H}_{2} \mathrm{O}(0.25 \mathrm{~g} / \mathrm{L})$.

The test medium was prepared by adding solution A $(10 \mathrm{~mL})$, solutions $\mathrm{B}, \mathrm{C}$, and $\mathrm{D}$ (1 $\mathrm{mL}$ of each) to about $500 \mathrm{~mL}$ of water and bringing the volume to $1000 \mathrm{~mL}$ with water. The inoculum solution was prepared as described below. A sample was drawn from the soil, diluted with water in order to reach the final total solids concentration of $200 \mathrm{~g} / \mathrm{L}$, and aerated for $4 \mathrm{~h}$. Each vessel was filled with $380 \mathrm{~mL}$ of test medium and inoculated with $20 \mathrm{~mL}$ of inoculum solution. Test or reference material was added to each vessel $(50 \mathrm{mg})$, with the exception of the blanks. Two replicates were used for each material. The tests were stopped when $\mathrm{O}_{2}$ consumption was no longer detectable, in all cases at least after three months. The Oxitop system used in the determination of BOD contains an individual number of reactors, consisting of glass bottles with a carbon dioxide trap (sodium hydroxide) in the headspace. The bottles are supplied with a magnetic stirrer and sealed with a cap containing an electronic pressure indicator.

Afterwards, each vessel was kept under aeration for 15 min to restore the original oxygen concentration of the liquid medium. The vessels were then closed and put back in incubation. The net biochemical oxygen demand (BOD) of the test material was calculated as the difference between oxygen consumption in the test and the blank flasks using the equation:

net $B O D=B O D_{t m}-B O D_{b}$

where $\mathrm{BOD}_{\mathrm{tm}}$ is the total biochemical oxygen demand of the test material; $\mathrm{BOD}_{\mathrm{b}}$ is the biochemical oxygen demand of the blanks.

The percentage of biodegradation, $D_{t m}$, was calculated as the ratio of the net biochemical oxygen demand to the total theoretical oxygen demand (total ThOD, referred to the amount of test material introduced originally in the flask) using Equation (4):

$D_{\text {tm }}=\frac{\text { net } B O D}{\text { total } T h O D} \times 100$ 
where $\mathrm{D}_{\mathrm{tm}}$ : percentage of biodegradation; net BOD: specific Biochemical Oxygen Demand (in $\mathrm{mg} \mathrm{O}_{2} / \mathrm{L}$ ); ThOD: Theoretical Oxygen Demand (in $\mathrm{mg} \mathrm{O}_{2} / \mathrm{L}$ ).

The ThOD of the polymer $n\left(\mathrm{C}_{\mathrm{c}} \mathrm{H}_{\mathrm{h}} \mathrm{O}_{\mathrm{o}} \mathrm{N}_{\mathrm{n}} \mathrm{S}_{\mathrm{s}}\right)$, with a relative molecular mass $\mathrm{Mr}$ (per monomer), was calculated according to:

ThOD $=\frac{31.9988(c+0.25(h-3 n)+1.5 s-0.5 o)}{M_{r}}$

The experiments were incubated for 40 days and repeated twice. In both cases, after this period, oxygen consumption in respirometers was no longer detectable.

\section{RESULTS AND DISCUSSION \\ Modification procedure}

This modification was established in two stages: the first one is an addition reaction between the 1,6-HDI and the following fluorinated compounds $\left(\mathrm{C}_{6} \mathrm{~F}_{13} \mathrm{OH}, \mathrm{C}_{6} \mathrm{~F}_{13} \mathrm{SH}\right.$ and $\mathrm{C}_{6} \mathrm{~F}_{13} \mathrm{C}_{2} \mathrm{H}_{4} \mathrm{SH}$ ), respectively, (Fig. 1a) which leads to the formation of blocked isocyanate precursors. This modification was followed by FTIR analysis, and all the spectra of these precursors showed a new sharp peak around $2270 \mathrm{~cm}^{-1}$, assigned to the NCO group situated at their end. The second part is a reaction between these precursors resulted from the first stage (blocked isocyanate) and cellulose or CA (Fig. 1b). Figure 1 illustrates this grafting method. The products were obtained with great selectivity and high yields. Then, they were characterized using different spectroscopy techniques, such as FTIR and NMR.

(a)

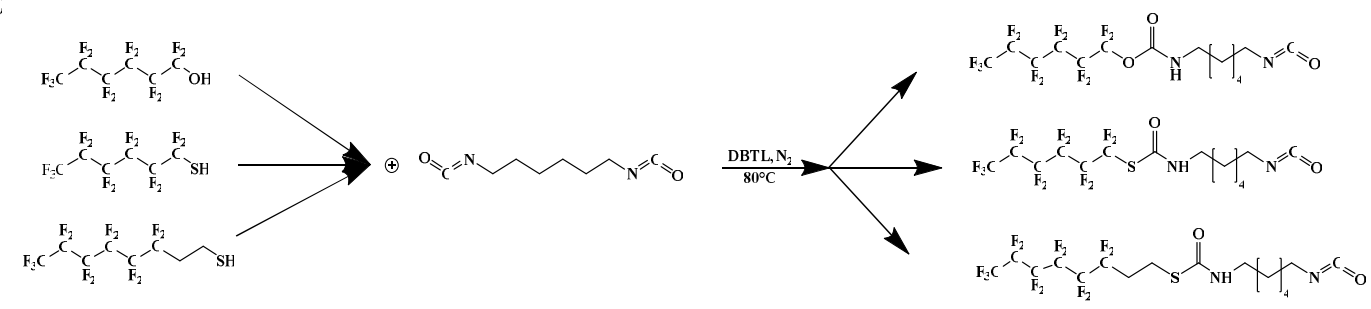

(b)

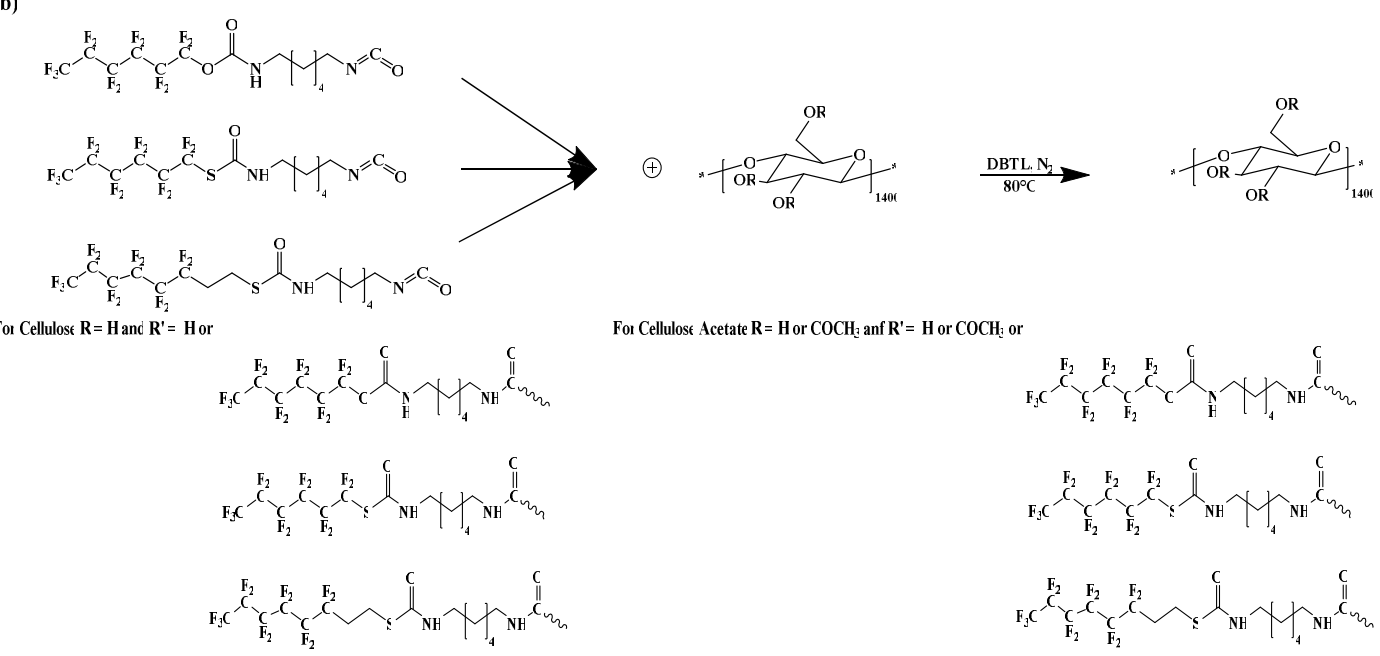

Figure 1: Preparation of (a) the precursor (HDI-R), and of (b) fluorinated cellulose (Cell-HDI-P1, Cell-HDI-P2 and

Cell-HDI-P3) and fluorinated CA (CA-HDI-P1, CA-HDI-P2 and CA-HDI-P3)

\section{NMR analysis}

On the ${ }^{1} \mathrm{H}$ NMR spectra of the fluorinated cellulose derivatives (Cell-HDI- $\left.\mathrm{P}_{2}\right)$ and fluorinated CA derivatives (CA-HDI- $\mathrm{P}_{2}$ ), for example (Fig. 2a and 2b), some signals between $1.07 \mathrm{ppm}$ and $2.95 \mathrm{ppm}$ appeared, indicating that the modifications of cellulose and CA by the aliphatic chain (HDI-CFSH) occurred. In addition, the peak of $\mathrm{CH}_{3}$ of $\mathrm{CA}$ appeared at 2.02 $\mathrm{ppm}$. The peaks of the carbamate group (-NHCO$\mathrm{O}-)$ appeared at 5.78 and at $6.30 \mathrm{ppm}$ for CellHDI- $\mathrm{P}_{2}$ and CA-HDI- $\mathrm{P}_{2}$ respectively, and the peaks of the thiocarbamate group (-NHCO-S-) appeared at $7.78 \mathrm{ppm}$ and at $7.74 \mathrm{ppm}$ for CellHDI- $\mathrm{P}_{2}$ and CA-HDI- $\mathrm{P}_{2}$, respectively. The signals of the cellulose backbone appeared between 3.04 
and 4.78 and the protons of the methylene group $\left(-\mathrm{CH}_{2}-\right)$ in the cellulose backbone gave a signal at $4.47 \mathrm{ppm}$. Finally, the signals of the CA backbone appeared between 3.09 and 4.80, and the protons of the methylene group $\left(-\mathrm{CH}_{2}-\right)$ in the $\mathrm{CA}$ backbone gave a signal at $4.55 \mathrm{ppm}$.

(a)

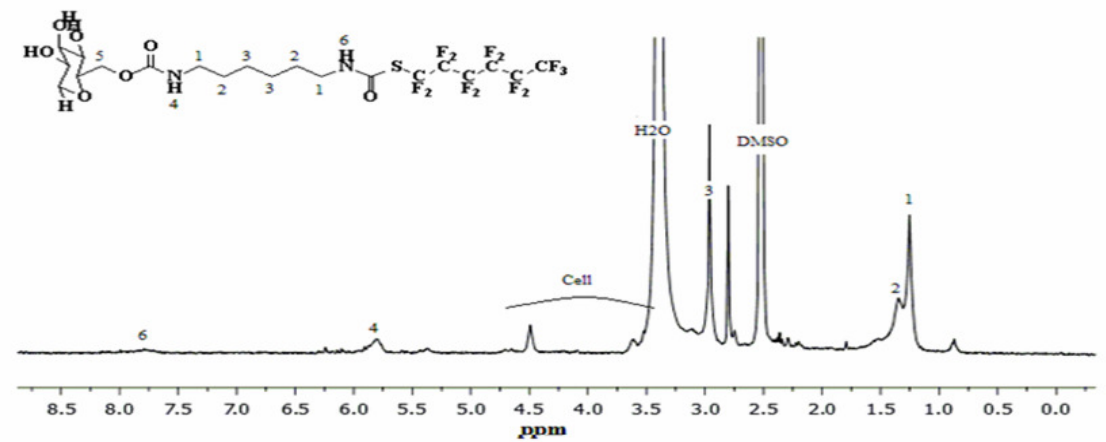

(b)

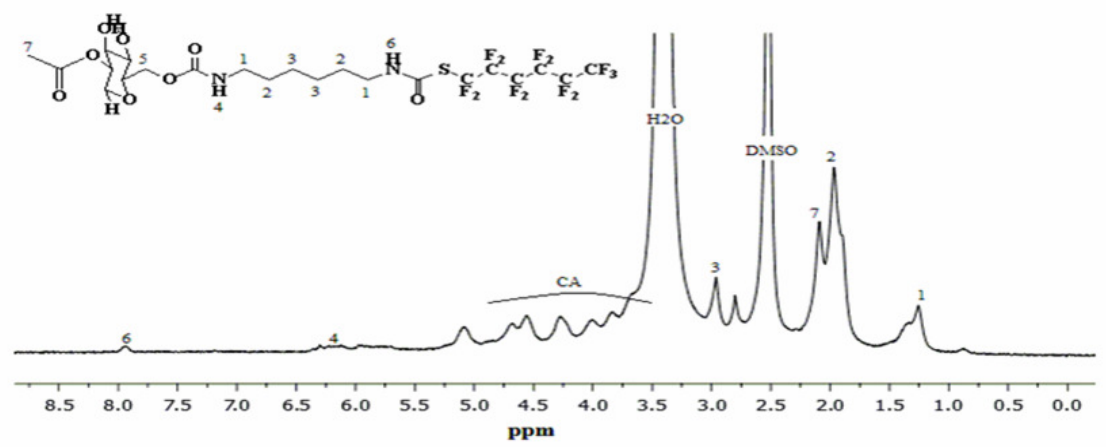

Figure 2: Examples of ${ }^{1} \mathrm{H}$ NMR spectra of (a) Cell-HDI- $\mathrm{P}_{2}$ and (b) CA-HDI- $\mathrm{P}_{2}$

\section{FTIR analysis}

The chemical structures of cellulose, CA and their fluorinated derivatives were characterized using FTIR spectroscopy. Figure 3 shows the main infrared spectral differences recorded as their characteristic peaks. The cellulose spectrum shows various bands (Fig. 3a) attributed to hydroxyl groups (3200-3600 cm-1), $\mathrm{C}-\mathrm{H}$ and $\mathrm{CH} 2$ groups stretching $(2700-3000 \mathrm{~cm}-$ 1), C-O stretching (1000-1300 cm-1), C-O-C stretching $(\sim 1164 \mathrm{~cm}-1)$ and glycosidic linkages $(\sim 895 \mathrm{~cm}-1){ }^{53}$ The grafting of the precursor compounds (HDI-R) onto cellulose and CA, respectively, shows that the NCO peak at 2270 cm-1 disappears in the resulted FTIR spectra, which means that the NCO group has been integrated into the carbamate group and this procedure was successful. The FTIR study on the $-\mathrm{NH}$ and $-\mathrm{C}=\mathrm{O}$ regions provides a powerful method for evaluating the formation of carbamate groups. $^{54}$

The derivatives (Cell-HDI-P ${ }_{1}$, Cell-HDI-P ${ }_{2}$ and Cell-HDI-P ) (Fig. 3a) show an absorption band around $3340 \mathrm{~cm}^{-1}$ associated with $\mathrm{NH}$ group stretching vibrations. The absorption bands at around 2859 and $2930 \mathrm{~cm}^{-1}$ are due to the $\mathrm{CH} / \mathrm{CH}_{2}$-stretching vibrations, and those at around 1690 and $1730 \mathrm{~cm}^{-1}$ might be due to the thiocarbamate and carbamate (NHCOS and NHCOO) stretching vibrations, respectively. Most of the absorption bands at around 1140 and $1000 \mathrm{~cm}^{-1}$ are related to the $\mathrm{C}-\mathrm{O}-\mathrm{C}$ and $\mathrm{C}-\mathrm{F}$ stretching vibration and those at around $600 \mathrm{~cm}^{-1}$ are attributed to the stretching vibrations of C-S bands for Cell-HDI- $P_{2}$ and Cell-HDI- $P_{3}$. Finally, the absorption band around $1500 \mathrm{~cm}^{-1}$ is assigned to the bending vibration of $\mathrm{NH}$. These results are in agreement with those reported in the literature. ${ }^{45}$ In Figure $3 \mathrm{~b}$, the FTIR spectrum of the CA shows an absorption band located at 1751 $\mathrm{cm}^{-1}$, which is assigned to the stretching vibration of the ester group $\left(\mathrm{CH}_{2} \mathrm{CO}\right)$.

Furthermore, a decrease in the absorption intensity of the band located at around $3431 \mathrm{~cm}^{-1}$, which is assigned to the stretching of the hydroxyl groups, is observed. This decrease indicates that 
the hydroxyl groups of cellulose are substituted by acetyl groups. ${ }^{55}$ As regards the FTIR spectra of the products $\left(\mathrm{CA}-\mathrm{HDI}-\mathrm{P}_{1}, \mathrm{CA}-\mathrm{HDI}-\mathrm{P}_{2}\right.$ and $\mathrm{CA}-$ HDI- $\mathrm{P}_{3}$ ), resulting from the reaction between the residual hydroxyl groups in $\mathrm{CA}$ and the precursor compound, having a free isocyanate group (HDI$\mathrm{P}_{1}$, HDI- $\mathrm{P}_{2}$ or HDI- $\mathrm{P}_{3}$ ), several novel absorption bands resulted. The peaks at around 1690, 1700

(a)

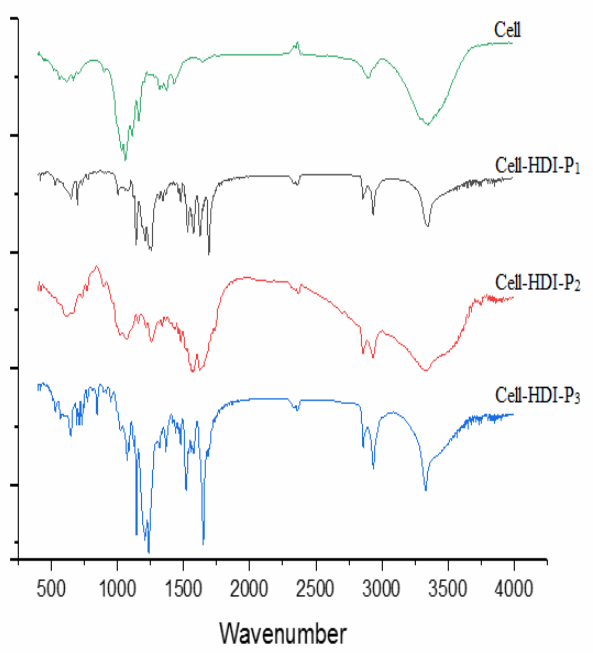

and $1750 \mathrm{~cm}^{-1}$ are attributed to the stretching vibration of the thiocarbamate (-NHCOS-), the carbamate function (-NHCOO-) and the ester group ( $\left.\mathrm{CH}_{3} \underline{\mathrm{COO}}-\right)$, respectively. Those appearing at around 1140 and $1050 \mathrm{~cm}^{-1}$ are assigned to the absorption bands due to the stretching vibration of the $\mathrm{C}-\mathrm{F}$ and $\mathrm{C}-\mathrm{O}-\mathrm{C}$ bonds.

(b)

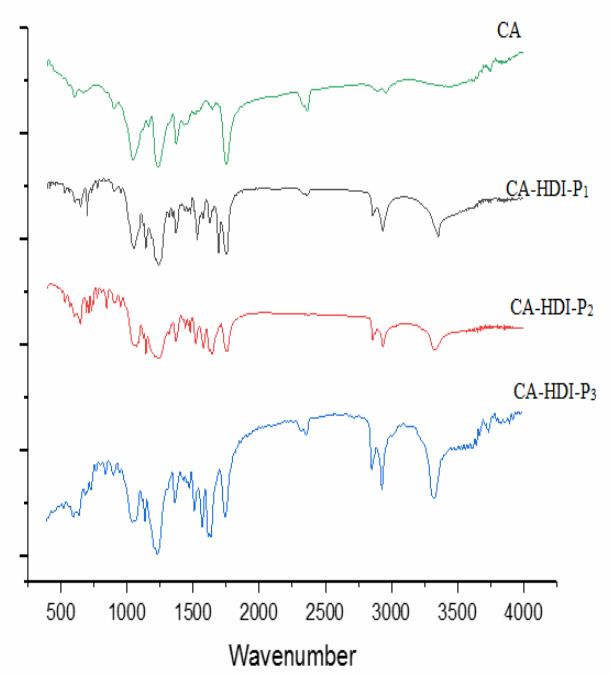

Figure 3: FTIR spectra of (a) Cell, Cell-HDI- $\mathrm{P}_{1}$, Cell-HDI- $\mathrm{P}_{2}$ and Cell-HDI- $\mathrm{P}_{3}$, as well as of (b) CA, CA-HDI-P 1 , CA-HDI-P 2 and CA-HDI-P 3

Moreover, at around $3300 \mathrm{~cm}^{-1}$, absorption bands appeared due to the stretching vibration of $\mathrm{N}-\mathrm{H}$ and the bending vibration of these bands is around $1520 \mathrm{~cm}^{-1}$. In addition, the increase in the absorption band at around 2800 and $2900 \mathrm{~cm}^{-1}$ indicated that the grafting was established. These bands are attributed to the stretching vibration of $\mathrm{CH} / \mathrm{CH}_{2}$ bonds. Table 1 summarizes the most important peaks detected for all the products in the FTIR spectra.

\section{Thermal analysis}

The thermal degradation of cellulose, CA, the fluorinated cellulose/CA derivatives was studied using thermogravimetric analysis (TGA/DTG). Figure 4 shows examples of TGA and DTG curves, illustrating the weight loss of the samples. The cellulose exhibits a slight initial loss between $30-220{ }^{\circ} \mathrm{C}$ (elimination of residual water) and a major decomposition proceeds from $220{ }^{\circ} \mathrm{C}$ to $400{ }^{\circ} \mathrm{C}$. This step shows the maximum peak $\left(\mathrm{T}_{\max }\right)$ at $370{ }^{\circ} \mathrm{C}$ (Fig. 4b). The residual weight (about 6\%) is comparable to that of neat cellulose under similar conditions. The main residues (about 6\%) are attributed to the formation of char, because the decomposed products are easily volatilized. This result was also confirmed by other studies. 53

The Cell-HDI- $P_{1}$ derivative shows a first loss of mass corresponding to the elimination of humidity and desorption of gases between 30-120 ${ }^{\circ} \mathrm{C}$, a second loss of weight occurs between 150 ${ }^{\circ} \mathrm{C}$ and $380{ }^{\circ} \mathrm{C}$, composed in fact of two transitions attributed to the detachment of the graft chains and to the degradation of the main cellulose chain. The final step is situated in the temperature range of $390-550{ }^{\circ} \mathrm{C}$, and is mainly attributed to the thermal decomposition of fluorinated compound chains. The high temperature value is due to the stability of $\mathrm{C}-\mathrm{F}$ bonds. This step is confirmed by an intense endothermic peak with a maximum at $540{ }^{\circ} \mathrm{C}$. Cell-HDI-P ${ }_{2}$ and Cell-HDI-P ${ }_{3}$ also show behaviors with three main steps of weight loss (Fig. 4b). The first loss is observed between 30 and $200{ }^{\circ} \mathrm{C}$, and is due to the elimination of residual solvent, especially residual water having some interactions with the cellulosic backbone chain. 
Table 1

FTIR absorption bands of fluorinated cellulose carbamates and fluorinated CA carbamates

\begin{tabular}{|c|c|c|c|c|c|c|}
\hline \multirow{3}{*}{ Functional groups } & \multicolumn{6}{|c|}{ Wavenumber $\left(\mathrm{cm}^{-1}\right)$} \\
\hline & \multicolumn{3}{|c|}{ Cellulose carbamate } & \multicolumn{3}{|c|}{ Cellulose acetate carbamate } \\
\hline & Cell-HDI-P 1 & Cell-HDI-P 2 & Cell-HDI-P $_{3}$ & CA-HDI-P $_{1}$ & CA-HDI-P 2 & CA-HDI-P 3 \\
\hline NH (stretching vibration) & 3352 & 3339 & 3331 & 3354 & 3327 & 3325 \\
\hline $\mathrm{CH} / \mathrm{CH}_{2}$ (stretching vibration) & 2857 and 2936 & 2857 and 2934 & 2858 and 2936 & 2857 and 2936 & 2859 and 2936 & 2858 and 2936 \\
\hline $\mathrm{CH}_{2} \mathrm{C}=\mathrm{O}$ (stretching vibration) & - & - & - & 1755 & 1755 & 1749 \\
\hline $\mathrm{HN}-\mathrm{C}=\mathrm{OO}$ (stretching vibration) & 1693 & 1734 & 1717 & 1693 & 1686 & 1734 \\
\hline $\mathrm{NH}-\mathrm{C}=\mathrm{OS}$ (stretching vibration) & 1624 & 1651 & 1647 & 1624 & 1643 & 1647 \\
\hline $\mathrm{C}-\mathrm{N}$ (stretching vibration) & 1259 & 1254 & 1236 & 1240 & 1236 & 1234 \\
\hline $\mathrm{N}-\mathrm{H}$ (bending vibration) & 1533 & 1564 & 1520 & 1531 & 1520 & 1522 \\
\hline $\mathrm{C}-\mathrm{O}-\mathrm{C}$ (stretching vibration) & 1144 & 1157 & 1144 & 1142 & 1144 & 1144 \\
\hline C-F (stretching vibration) & 1007 & 1070 & 1074 & 1053 & 1074 & 1049 \\
\hline C-S (stretching vibration) & - & 621 & 648 & - & 648 & 646 \\
\hline
\end{tabular}


FATIMA EZAHRA TABAGHT et al.

The second step represents the decomposition of the grafted groups attached on the cellulose main chain and is situated between 200 and $380{ }^{\circ} \mathrm{C}$. The last step is a loss phenomenon mainly attributed to the thermal decomposition of fluorinated chain, which is confirmed by an intense endothermic peak at $540{ }^{\circ} \mathrm{C}$. Comparing the results of the present study with those reported on the modification by thiol compounds, ${ }^{56}$ it was found that the fluorinated compounds present higher thermal stability than thiol compounds.

In the case of $\mathrm{CA}$, the thermal decomposition occurred in three steps (Fig. $4 \mathrm{c})$. The first one is before $240{ }^{\circ} \mathrm{C}$ and represents the volatilization of residual absorbed water and solvents. The second step, from $240{ }^{\circ} \mathrm{C}$ to $420{ }^{\circ} \mathrm{C}$, represents the thermal degradation of the cellulose acetate main chains. A weak third step starts at $430{ }^{\circ} \mathrm{C}$ and may be attributed to ash formation.
The TGA and DTG curves of CA-HDI- ${ }_{1}$, CA-HDI- $\mathrm{P}_{2}$ and CA-HDI- $\mathrm{P}_{3}$ derivatives show three major slopes of weight loss. They start to degrade after the elimination of the solvents, especially residual water. It should be noted that the stability of fluorinated compounds is relatively improved compared to the CA due to the presence of the fluorinated chains grafted onto the cellulose. The derivatives CA-HDI-P and CA-HDI- $\mathrm{P}_{2}$ show two other transitions. The first approximately between 200 and 380 ${ }^{\circ} \mathrm{C}$, corresponding to the detachment of the grafted groups and $\mathrm{CA}$ main chain degradation, and the second between 430 and $520{ }^{\circ} \mathrm{C}$, which may be due to the decomposition of the fluorinated compounds main chain.

In conclusion, these fluorinated materials show better thermal stability compared to the starting materials (cellulose and CA). (a)

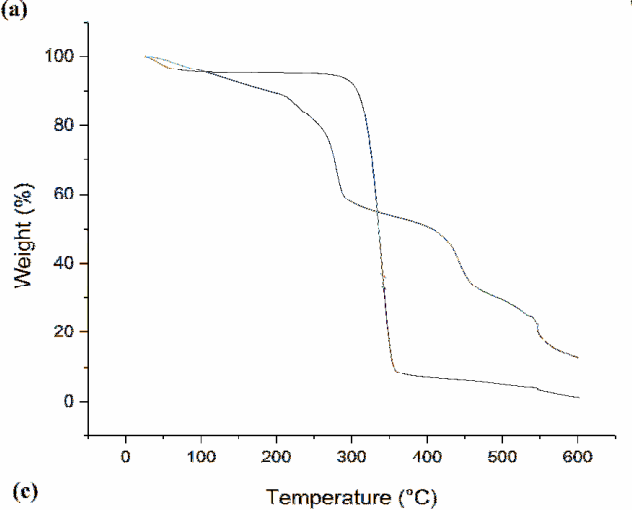

(c)

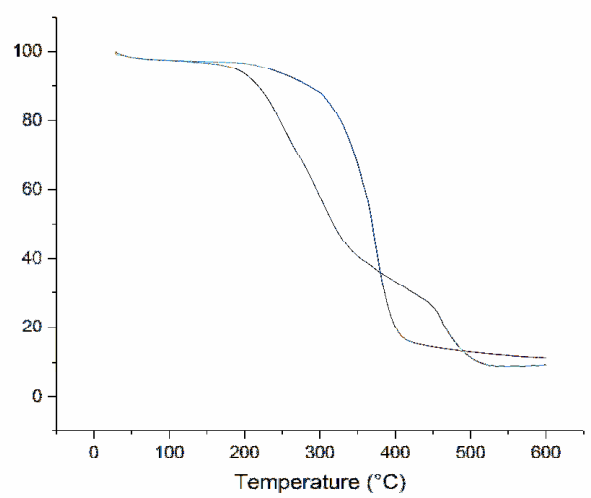

(b)
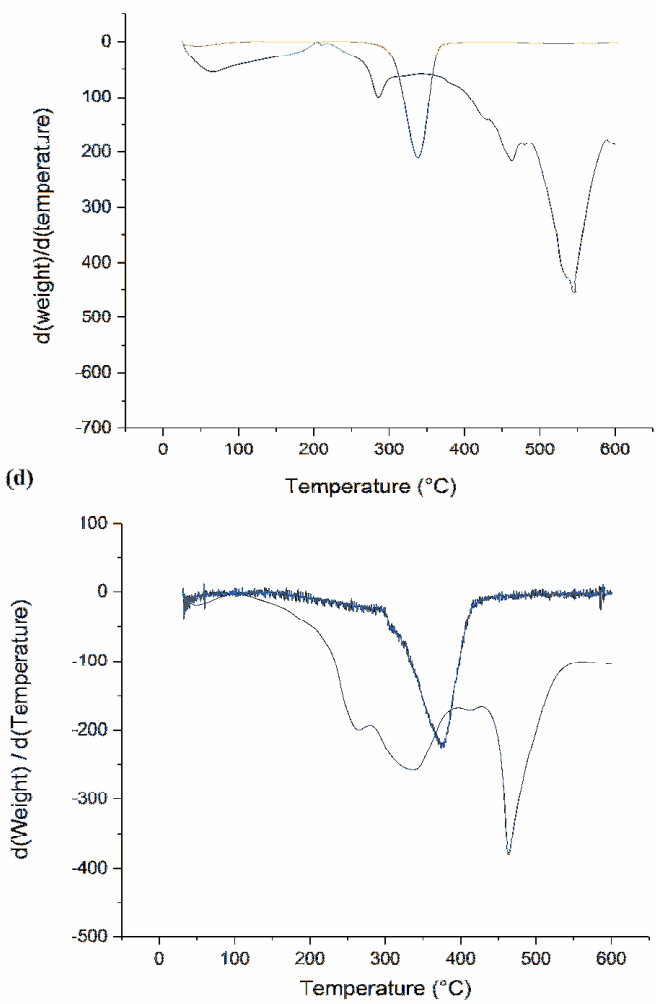

Figure 4: Examples of (a) TGA thermograms of cellulose and Cell-HDI- $\mathrm{P}_{2}$, (b) DTG thermograms of cellulose and Cell-HDI- $\mathrm{P}_{2}$, (c) TGA thermograms of CA and CA-HDI- $\mathrm{P}_{2}$ and

(d) DTG thermograms of CA and CA-HDI- $P_{2}$ 


\section{XRD analysis}

XRD results reveal some important pieces of information about the grafted reactions and the lattice of cellulose and CA. The XRD patterns of the cellulose, Cell-HDI- $\mathrm{P}_{1}$, CellHDI- ${ }_{2}$, Cell-HDI-P, CA, CA-HDI- ${ }_{1}$, CellHDI- $P_{2}$ and CA-HDI- $\mathrm{P}_{3}$ are presented in Figure 5. It can be seen that cellulose has $2 \theta$ diffraction peaks at $13.82^{\circ}, 16.30^{\circ}, 22.04$ and $34.10^{\circ}$, justifying the typical cellulose I crystalline form. ${ }^{57}$ Furthermore, the XRD patterns of Cell-HDI-P $P_{1}$ derivative display

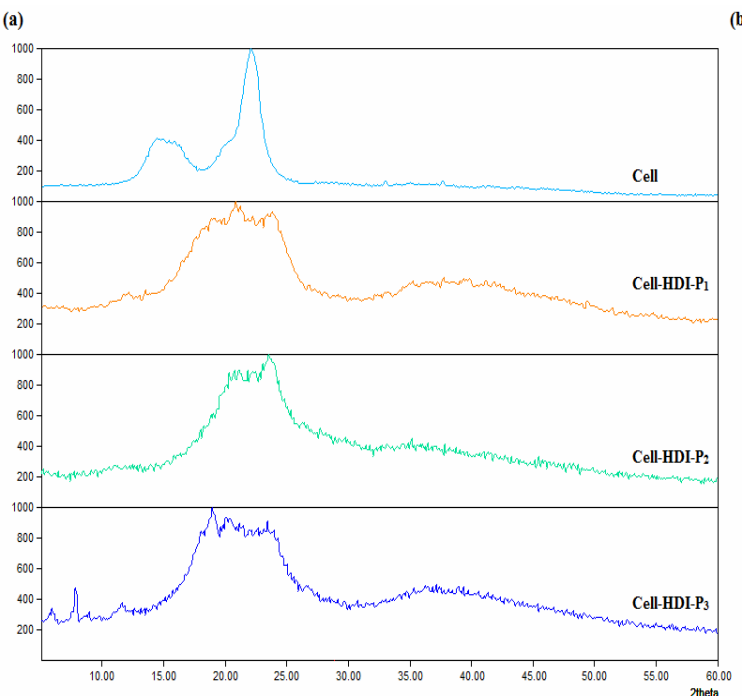

some new peaks around $2 \theta=17.84^{\circ}, 20.95^{\circ}$, $23.73^{\circ}$ and $24.54^{\circ}$, showing the presence of new crystal planes, which indicates that the grafting process was successful and that a change occurs in the morphology of cellulose. The same change was noted for Cell-HDI- $\mathrm{P}_{2}$ and Cell-HDI-P ${ }_{3}$, their XRD patterns show new peaks at $17.48^{\circ}, 19.74^{\circ}, 23.62^{\circ}, 24.70^{\circ}$ and $26.85^{\circ}$ for Cell-HDI- $\mathrm{P}_{2}$, and at $16.46^{\circ}$, $18.99^{\circ}, 23.38^{\circ}$ and $24.66^{\circ}$ for Cell-HDI-P . $_{3}$ The morphology of cellulose has greatly changed. (b)

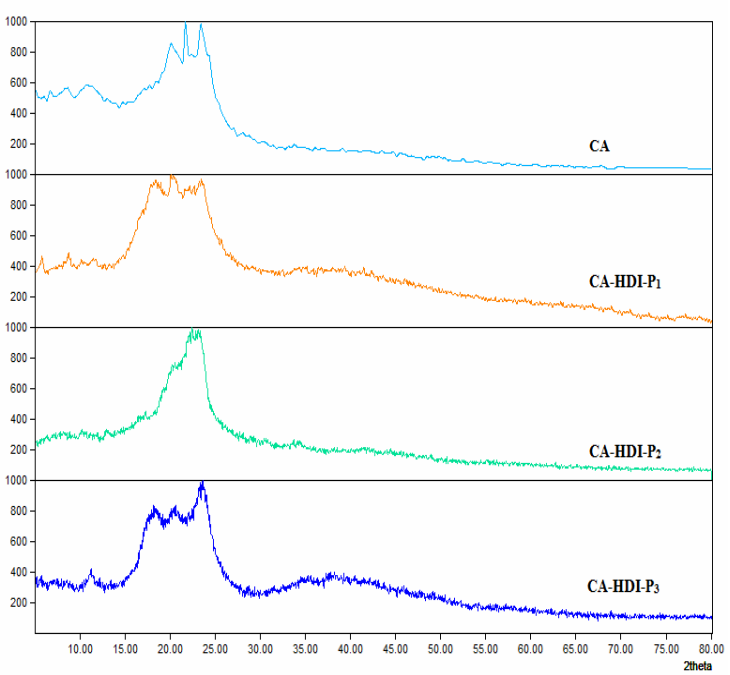

Figure 5: XRD spectra of (a) cellulose, Cell-HDI- $\mathrm{P}_{1}$, Cell-HDI- $\mathrm{P}_{2}$, and Cell-HDI-P ${ }_{3}$ and (b) CA, CA-HDI- $\mathrm{P}_{1}$, CA-HDI-P 2 and CA-HDI-P 3

CA presents a lower degree of crystallinity $(63 \%)$, compared to the cellulose $(88 \%)$ due to the substitution of the hydroxyl groups by acetyl groups, thus the inter- and intramolecular hydrogen bonds were partially eliminated. ${ }^{58}$ The XRD pattern of CA in Figure $5 \mathrm{~b}$ shows diffuse peaks around $2 \theta=8.05^{\circ}$, $20.75^{\circ}, 24.09^{\circ}, 41.47^{\circ}$ and $49.49^{\circ}$, with two maxima at $2 \theta=17^{\circ}$ and at $24^{\circ}$, showing its semi-crystalline appearance.$^{55,59}$ The main peak located at approximately $8.05^{\circ}$ is cited as the principal characteristic of the semi-crystalline behavior of $\mathrm{CA}^{55}$ Furthermore, the major reflections for CA-HDI-P ${ }_{1}, \mathrm{CA}-\mathrm{HDI}-\mathrm{P}_{2}$ and for CA-HDI- $\mathrm{P}_{3}$ are at $2 \theta=17.70^{\circ}, 20.39^{\circ}$ and $23.48^{\circ}$, at $2 \theta=16.49^{\circ}, 21.50^{\circ}, 22.38^{\circ}$ and $25.09^{\circ}$ and at $2 \theta=11.08^{\circ}, 17.74^{\circ}, 20.21^{\circ}$, $23.57^{\circ}$ and $24.24^{\circ}$, respectively. A great change was noted between the XRD spectrum of CA and those of fluorinated CA carbamates.
The $\mathrm{I}_{\mathrm{Cr}}$ decreases from $88 \%$ for cellulose to $21 \%$ for Cell-HDI-P $\mathrm{P}_{1}$, to $54 \%$ for Cell-HDI-P and to $23 \%$ for Cell-HDI-P $\mathrm{P}_{3}$. This decreasing indicates that the content of the amorphous regions increases significantly, allowing their modification and transformation to occur easily. ${ }^{60}$ In addition, this fact indicates that these products have lost their crystallinity after fiber modification. For CA and fluorinated CA carbamates, a small variation in the crystallinity index between CA (63.98\%), CAHDI-P $1(12.50 \%)$, CA-HDI-P 2 (52.70\%) and CA-HDI-P $(27 \%)$ was observed. It is noted that Cell-HDI-P ${ }_{2}$ and CA-HDI-P ${ }_{2}$ keep a larger value for $\mathrm{I}_{\mathrm{Cr}}$, compared to their counterparts. The X-ray diffraction studies showed that crystallinity depends greatly on the structure of the reagents and the reaction conditions. 


\section{Solubility study}

The solubility behavior is an important parameter that characterizes the miscibility of a system under a qualitative aspect. ${ }^{17}$ According to our recent study, it is well-known that the introduction of fluorinated compounds on the cellulose and CA backbones leads to a change in their solubility in some solvent systems. Table 2 lists the solubility of fluorinated cellulose carbamates and fluorinated CA carbamates in various solvent systems. It is worth noticing, according to this study, that these derivatives show almost the same solubility, they are soluble in DMSO. Moreover, CA-HDI- ${ }_{1}$, Cell-HDI- ${ }_{2}$, CellHDI- $\mathrm{P}_{3}$ and CA-HDI- $\mathrm{P}_{3}$ show higher solubility in DMF, and CA-HDI-P ${ }_{1}$ and CA-HDI-P 3 derivatives are soluble at high temperature and partially soluble at room temperature in dichloromethane and DMAc, respectively. In summary, their solubilities improved because fluorinated cellulose carbamates and fluorinated CA carbamates became hydrophobic and interchain interactions were destroyed. Consequently, they show a good solubility phenomenon in polar aprotic solvent systems and, respectively, a low solubility phenomenon in non-polar aprotic solvent systems at room temperature.

\section{Biodegradability study}

The first test method used was an attempt to simulate the conditions experienced by a biocomposite when buried under environmental conditions. The test has been conceived as a qualitative test based simply on visual assessment. The second test method was intended to determine the biochemical oxygen demand (BOD) in a closed respirometer. The biodegradability study of the blank, cellulose, Cell-HDI-P ${ }_{1}$, Cell-HDI-P ${ }_{2}$, Cell-HDI-P ${ }_{3}$, CAHDI-P ${ }_{1}$ CA-HDI-P ${ }_{2}$ and CA-HDI-P 3 was conducted under aerobic solid and liquid conditions according to ASTM (G21-70, G2276 and G29-75), AFNOR (X 41-514-81 and X41-517-69), DIN 53739, ISO 846 and ISO 14851 .

Firstly, the aerobic biodegradation experiments under solid conditions were validated by visual assessment (qualitative information), showing the amount of growth on the surface of the material or clear areas due to the hydrolysis of the substrate by the enzymes released by the microorganisms. Thanks to the clarity of the Petri dish, the biodegradation progress can be closely correlated with the disappearance of the specimens, confirming that the development of microorganisms is actually linked to the rate of biodegradation. Figure 6 summarizes the evolution of the biodegradation of the blank test, cellulose, CA and their derivatives under aerobic solid conditions. After 28 days of incubation, it is noted visually that cellulose, $\mathrm{CA}$ and the derivatives already cited were largely colonized by the micro-organisms and the blank test did not show any development of the microorganisms, indicating that the microorganisms that grew on the solid medium containing cellulose, $\mathrm{CA}$ and their derivatives were capable of degrading and using it as the sole carbon source.

The aerobic biodegradation experiments in liquid conditions were validated by a method named biochemical oxygen demand (BOD) using a closed respirometer. The BOD is the quantity of $\mathrm{O}_{2}$ indispensable for a biodegradation step and it was determined using standard ISO 14851 (1999) during 40 days. The methodology is explained in detail in the experimental part. The ThOD is expressed as the mass of $\mathrm{O}_{2}$ per mass of polymer, and it was determined by calculating the amount of $\mathrm{O}_{2}$ necessary for aerobic mineralization of the cellulose derivatives, i.e., complete oxidation of carbon to $\mathrm{CO}_{2}$.

The rate of degradation is very much dependent upon the biodegradation conditions (solid, liquid medium) and the chemical structure of the sample submitted to a biodegradation test.

According to the curves plotted in Figure 7, it should be noted that the degradation kinetics of the studied samples show a slight variation. As we know, two key steps occur in the polymer degradation process: first, depolymerization, or a chain cleavage step, and second, a mineralization process. The first step normally occurs outside the micro-organism due to the size of the polymer chain and its insoluble nature. Once sufficiently formed, the smallsize oligomeric or monomeric fragments are transported into the cell where they are mineralized. ${ }^{61}$ The biodegradation process of cellulose, $\mathrm{CA}$ and the fluorinated derivatives (Cell-HDI-P ${ }_{1}$, Cell-HDI-P 2 , Cell-HDI- ${ }_{3}$, CAHDI- $\mathrm{P}_{1}$, CA-HDI-P ${ }_{2}$ and CA-HDI- $\mathrm{P}_{3}$ ) is represented by the evolution of the biodegradation percentage and the biodegradability rate. 
Table 2

Solubility test of Cell-HDI-P ${ }_{1}$, Cell-HDI-P ${ }_{2}$, Cell-HDI-P ${ }_{3}$, CA-HDI-P ${ }_{1}$, CA-HDI- $P_{2}$ and CA-HDI-P 3

\begin{tabular}{|c|c|c|c|c|c|c|c|}
\hline & & Cell-HDI-P 1 & Cell-HDI-P 2 & Cell-HDI-P 3 & CA-HDI-P 1 & CA-HDI-P 2 & CA-HDI-P 3 \\
\hline \multirow{4}{*}{$\begin{array}{l}\text { Polar } \\
\text { protic } \\
\text { solvents }\end{array}$} & Ethanol & - & - & - & - & - & - \\
\hline & Methanol & - & - & - & - & - & - \\
\hline & Water & - & - & - & - & - & - \\
\hline & Propane-2-ol & - & - & - & - & - & - \\
\hline \multirow{5}{*}{$\begin{array}{l}\text { Polar } \\
\text { aprotic } \\
\text { solvents }\end{array}$} & Dimethylsulfoxide & + & \pm & + & + & \pm & + \\
\hline & Dimethylformamide & - & \pm & \pm & \pm & - & \pm \\
\hline & Dimethylacetamide & - & - & - & \pm & - & \pm \\
\hline & Acetone & - & - & - & - & - & - \\
\hline & Acetonitrile & - & - & - & - & - & - \\
\hline \multirow{6}{*}{$\begin{array}{l}\text { Non-polar } \\
\text { aprotic } \\
\text { solvents }\end{array}$} & Chloroform & - & - & - & - & - & - \\
\hline & Dichloromethane & - & - & - & + & - & \pm \\
\hline & Toluene & - & - & - & - & - & - \\
\hline & Hexane & - & - & - & - & - & - \\
\hline & Tetrahydrofuran & - & - & - & - & - & - \\
\hline & Diethyl ether & - & - & - & - & - & - \\
\hline
\end{tabular}

+: Soluble, \pm : Partially soluble, -: Insoluble 


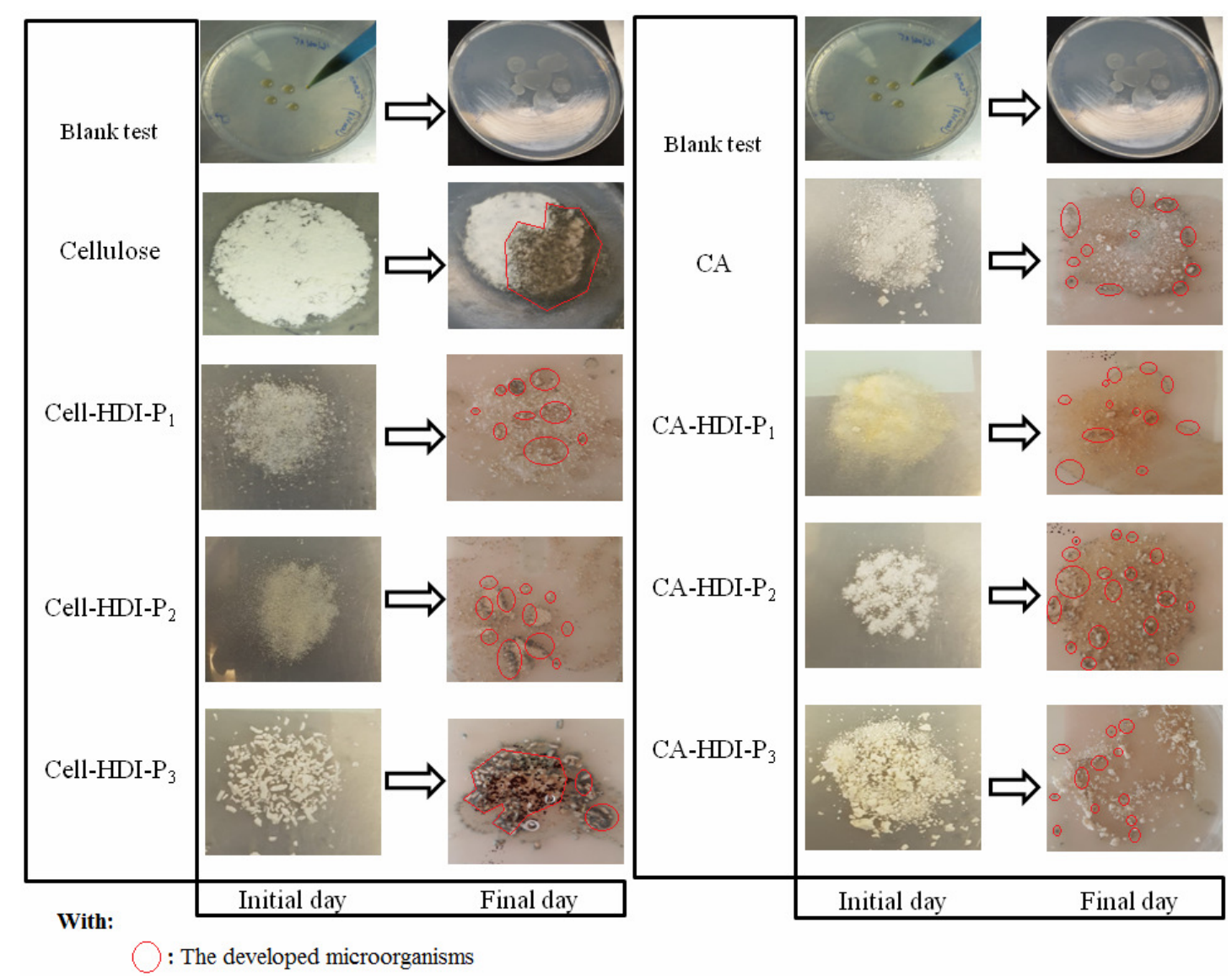

Figure 6: Evolution of biodegradation process of cellulose, CA and their derivatives after 28 days of incubation on solid medium

The results show that, whatever the cellulose, CA and their derivatives, the consumption of $\mathrm{O}_{2}$ confirms the multiplication and growth of aerobic bacteria and their ability to assimilate them as the only carbon source. The experimental results show that the cellulose is biodegraded over $72 \%$. The derivatives Cell-HDI- $\mathrm{P}_{\mathrm{i}}(\mathrm{i}=1,2,3)$ are biodegraded over $34 \%$. Indeed, Cell-HDI- $\mathrm{P}_{2}$ is biodegraded over $35 \%$, Cell-HDI- $\mathrm{P}_{3}$ is biodegraded over $35 \%$ (Fig. 7a). Certainly, CA is potentially degradable in the environment and its rate of biodegradation is very much influenced by the degree of substitution. ${ }^{62}$ In Figure $7 \mathrm{~b}, \mathrm{CA}$ is biodegraded over $62 \%$, CAHDI- $\mathrm{P}_{1}$ is biodegraded over $33 \%$. Furthermore, CA-HDI- $\mathrm{P}_{2}$ is biodegraded over $33 \%$ and the CA-HDI- $\mathrm{P}_{3}$ is biodegraded over $32 \%$. The experimental results suggest that the cellulose and CA were more biodegradable than their respective derivatives.
According to the shape of the curves obtained experimentally, we suggest that biodegradation can be associated to the exponential growth of microorganisms, indicating a high and rapid biodegradation process of these biopolymers. This phenomenon can be modeled approximately by an exponential equation:

$B D=B D_{0} e^{\beta *}$

ln $B D=\mu\left(t-t_{0}\right)+\ln B D_{0}$

where $\mathrm{BD}_{0}$ and $\mathrm{BD}$ represent, respectively, the biodegradation at $t_{0}$ and $t ; \mu$ represents the rate of biodegradation.

According to Equations 6 and 7, the rate of biodegradation $(\mu)$ of the tested biopolymers is 0.11 for cellulose, 0.06 for Cell- $\mathrm{P}_{1}, 0.079$ for Cell- $\mathrm{P}_{2}, 0.08$ for Cell- $\mathrm{P}_{3}, 0.12$ for CA, 0.096 for CA- $\mathrm{P}_{1}, 0.10$ for CA- $\mathrm{P}_{2}$ and 0.16 for CA-P (Table 3). 
(a)

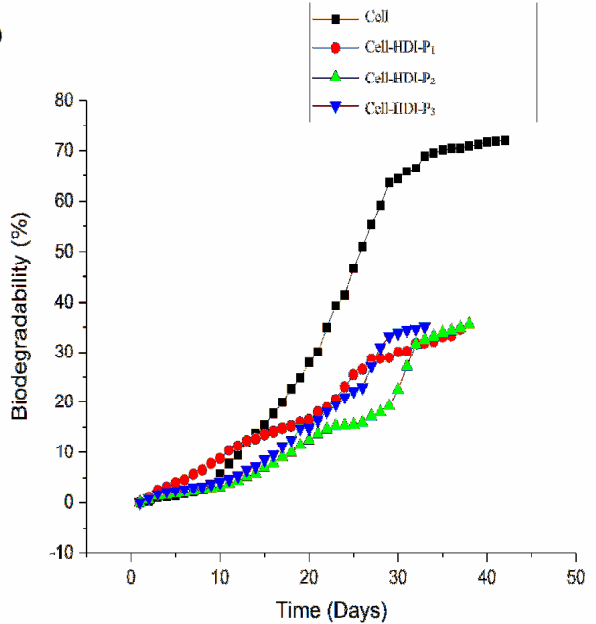

(b)

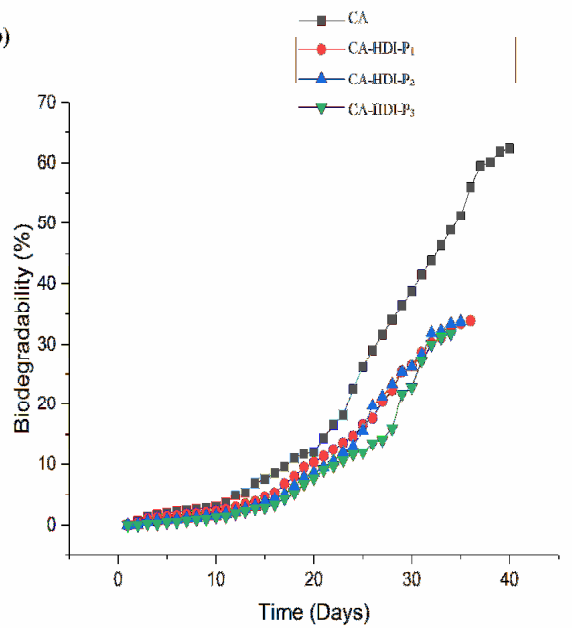

Figure 7: Biodegradation percentage of (a) cellulose and its derivatives; (b) CA and its derivatives after 40 days of incubation at $25^{\circ} \mathrm{C}$ in aerobic liquid medium

Table 3

Rate of biodegradation $(\mu)$ of the tested biopolymers

\begin{tabular}{lc}
\hline Biopolymer & Rate of biodegradation $(\mu)$ \\
\hline Cell & 0.11 \\
Cell- $\mathrm{P}_{1}$ & 0.06 \\
Cell- $\mathrm{P}_{2}$ & 0.079 \\
Cell-P & 0.08 \\
CA & 0.12 \\
CA-P $\mathrm{P}_{1}$ & 0.096 \\
CA-P & 0.10 \\
CA-P $_{3}$ & 0.16 \\
\hline
\end{tabular}

According to these results, the rate of biodegradation $(\mu)$ shows a slight variation in the case of cellulose derivatives and a rough comparison can be deducted Cell- $\mathrm{P}_{1}<$ Cell- $\mathrm{P}_{2}$ $<$ Cell- $\mathrm{P}_{3}<$ Cellulose and CA- $\mathrm{P}_{1}<$ CA-P $\mathrm{P}_{2}<$ $\mathrm{CA}<\mathrm{CA}-\mathrm{P}_{3}$. Hence, the introduction of the fluorinated functions in cellulose and CA reduced their biodegradation rate. This decrease can be explained by the presence of fewer ester groups, in all the fluorinated materials, except $\mathrm{CA}-\mathrm{P}_{3}$, which possesses a relatively moderate biodegradation rate. Microbial attack can occur by involving esterase enzymes. Fungi associated with biopolymers are known for their esterase production capacity on various plant polysaccharides. ${ }^{63}$ This variation in biodegradation rate can also be explained by the variation of crystallinity index (CrI) from cellulose or CA to their derivatives. Moreover, it is known that the biodegradation process is faster for amorphous regions, compared to crystalline ones. ${ }^{64}$

It is worth noting that the presence of carboxyl groups increases the ability of the composites to be degraded, but the introduction of fluorinated groups acts negatively in the biodegrading process because the fluorinated cellulose and the fluorinated CA have a biodegradation percentage that does not exceed $35 \%$ and the biodegradation rate is less than that of cellulose and CA. Moreover, we can conclude the environment used as inoculum has a biodegradation effect, and the growth of microorganisms is due to their ability to use these biopolymers as a sole carbon source.

\section{CONCLUSION}

In this study, the synthesis of novel fluorinated materials from cellulose and CA was conducted as described below. Firstly, a blocked isocyanate was prepared from a carbamation or thiocarbamation reaction between fluorinated compounds (alcohol and thiol) and (1,6)-HDI. Secondly, the obtained precursors were added to the cellulose and CA, respectively, in a homogeneous medium, yielding the desirable products with high selectivity and high yields. This procedure was 
carried out in one pot, avoiding the formation of residues and with an atomic economy of $100 \%$. The compounds prepared were characterized by Fourier transform infrared spectroscopy (FTIR), nuclear magnetic resonance (NMR), X-ray diffractometry (XRD), thermogravimetric analysis (TGA) and differential thermogravimetry (DTG) measurements.

The results obtained showed that the grafting process was successful and changes occurred in the morphology of cellulose and AC. In addition, the thermal behaviour of these new materials also exhibited better stability, compared to that of the reagents, due to the presence of fluorine. Moreover, these new materials exhibited better solubility compared to cellulose, but it decreased compared to AC. The phenomenon of biodegradation has been investigated by BOD and microbial growth methods. It has been shown that the introduction of fluorinated chains into the cellulose and AC chains backbone slightly reduced their rate of biodegradation, compared to the initial homologues. It can be concluded from this study that the fluorinated compounds may have applications in the antimicrobial field. These tests target environmentally friendly materials, the sustainability development and the enhancement in the discipline of green chemistry.

ACKNOWLEDGEMENT: The authors are grateful to Morocco CNRST - Program PPR/2015/17 - (Rabat) and to University Mohamed I - Program PARA - for their support to carry out this work and the laboratory associated contract.

\section{REFERENCES}

R. Muthuraj, M. Misra and A. K. Mohanty, "Biocomposites: Design and Mechanical Performance", Elsevier Ltd., Cambridge, 2015, https://doi.org/10.1016/B978-1-78242-3737.00014-7

2 Q. Xu, C. Chen, K. Rosswurm, T. Yao and S. Janaswamy, Carbohyd. Polym., 149, 274 (2016), https://doi.org/10.1016/j.carbpol.2016.04.114

3 Z. N. Terzopoulou, G. Z. Papageorgiou, E. Papadopoulou, E. Alexopoulou and D. N. Bikiaris, Ind. Crop. Prod., 68, 60 (2015), https://doi.org/10.1016/j.carbpol.2014.04.058

4 T. Nishino, K. Hirao, M. Kotera, K. Nakamae and H. Inagaki, Compos. Sci. Technol., 63, 1281 (2003),

https://doi.org/10.1016/j.progpolymsci.2006.03.002
5 B. Priya, V. K. Gupta, D. Pathania and A. S. Singha, Carbohydr. Polym., 109, 171 (2014), https://doi.org/10.1016/j.carbpol.2011.04.043

${ }^{6}$ K. Azzaoui, A. Lamhamdi, E. M. Mejdoubi, M. Berrabah, B. Hammouti et al., Carbohyd. Polym., 111, 41 (2014), https://doi.org/10.1016/j.compositesb.2012.04.053

7 L. Yu, K. Dean and L. Li, Prog. Polym. Sci., 31, 576 (2006), https://doi.org/https://doi.org/10.1163/15685540535 42188

8 M. Jawaid and H. P. S. Abdul Khalil, Carbohyd. Polym., $\quad 86, \quad 1 \quad$ (2011), https://doi.org/10.1016/j.compositesa.2005.04.015

9 M. M. Kabir, H. Wang, K. T. Lau and F. Cardona, Compos. Part B Eng., 43, 2883 (2012), https://doi.org/10.1016/j.carbpol.2014.02.016

10 M. N. Belgacem and A. Gandini, Compos. Interfaces, $\quad \mathbf{1 2}, \quad 41 \quad$ (2004), https://doi.org/10.1016/j.carbpol.2014.03.039

11 S. H. Lee and S. Wang, Compos. Part A Appl. Sci. Manuf., 37, $80 \quad$ (2006), https://doi.org/10.1016/j.indcrop.2014.08.034

12 V. Fiore, T. Scalici and A. Valenza, Carbohyd. Polym., 106, 77 (2014), https://doi.org/10.1016/S0266-3538(03)00099-X

13 V. K. Thakur and M. K. Thakur, Carbohyd. Polym., 109, 102 (2014), https://doi.org/10.1016/j.carbpol.2014.03.044

14 D. Roy, M. Semsarilar, J. T. Guthrie and S. Perrier, Chem. Soc. Rev., 38, 2046 (2009), https://doi.org/10.1039/b808639g

15 B. Ly, M. N. Belgacem, J. Bras and M. C. B. Salon, Mater. Sci. Eng. C, 30, 343 (2010), https://doi.org/10.1016/j.msec.2009.11.009

${ }^{16} \mathrm{X} . \mathrm{Fu}, \mathrm{T}$. Maruyama, T. Sotani and H. Matsuyama, J. Membrane Sci., 320, 483 (2008), https://doi.org/10.1016/j.memsci.2008.04.027

17 P. A. Dantas and V. R. Botaro, Open J. Polym. Chem., 2, $144 \quad$ (2012), https://doi.org/10.4236/ojpchem.2012.24019

18 R. O. Williams and J. Liu, Eur. J. Pharm. Biopharm., 49, $243 \quad$ (2000), https://doi.org/10.1016/S0939-6411(00)00065-5

${ }_{19}$ S. Hokkanen, A. Bhatnagar and M. Sillanpää, Water Res., 91, $156 \quad$ (2016), https://doi.org/10.1016/j.watres.2016.01.008

20 A. Carlmark, E. Larsson and E. Malmström, Eur. Polym. J., 48, $1646 \quad$ (2012), https://doi.org/10.1016/j.eurpolymj.2012.06.013

21 S. El Barkany, A. El Idrissi, C. Zannagui, F. Tabaght, A.-K. Maaroufi et al., Moroccan J. Chem., 4, 4, $743 \quad$ (2016), https://revues.imist.ma/index.php?journal=morjche m\&page $=$ article \&op $=$ view \& path $\% 5 B \% 5 \mathrm{D}=5265$

22 Y. Zhang, C. Yin, Y. Zhang and H. Wu,

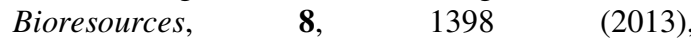
https://doi.org/10.15376/biores.8.1.1398-1408

${ }^{23}$ X. Wang, H. Y. Wu and C. Y. Yin, Adv. Mater. Res., $\quad \mathbf{8 2 1 - 8 2 2 ,} \quad 1031 \quad$ (2013), 
https://doi.org/10.4028/www.scientific.net/AMR.82 $1-822.1031$

24 M. Pinnow, H.-P. Fink, C. Fanter and J. Kunze, Macromol. Symp., 262, 129 (2008), https://doi.org/10.1002/masy.200850213

25 G. Yu, Y. Teng, W. Lai and C. Yin, Int. J. Biol. Macromol., $\quad 93, \quad 1155 \quad$ (2016), https://doi.org/10.1016/j.ijbiomac.2016.09.081

26 S. Eyley and W. Thielemans, R. Soc. Chem., 6, 7764 (2014), https://doi.org/10.1039/c4nr01756k

27 M. Bertoldo, F. Cognigni and F. Ciardelli, Polym. Bull., 66, $1015 \quad$ (2011), https://doi.org/10.1007/s00289-010-0327-5

28 T. Stahl, D. Mattern and H. Brunn, Environ. Sci. Eur., $\quad 23, \quad 1 \quad$ (2011), https://link.springer.com/content/pdf/10.1186/21904715-23-38.pdf

29 L. Jin, C. Jiang and P. Zhang, J. Environ. Sci., 51, 120

(2016),

https://doi.org/10.1016/j.jes.2016.08.010

30 B. Exner, B. Bayarmagnai, C. Matheis and L. J. Goossen, J. Fluor. Chem., 198, 89 (2016), https://doi.org/10.1016/j.jfluchem.2016.12.006

31 R. C. Buck, J. Franklin, U. Berger, J. M. Conder, I. T. Cousins et al., Integr. Environ. Assess. Manag., $\quad 7, \quad 513 \quad$ (2011), https://doi.org/10.1002/ieam.258

32 P. Riachy, G. Lopez, M. Emo, M. Stébé, J. Blin et al., J. Colloid Interface Sci., 487, 310 (2017), https://doi.org/10.1016/j.jcis.2016.10.053

33 M. Östenson, H. Järund, G. Toriz and P. Gatenholm, Cellulose, 13, 157 (2006), https://doi.org/10.1007/s10570-005-5855-z

34 H. Yuan, Y. Nishiyama and S. Kuga, Cellulose, 12, 543 (2005), https://doi.org/10.1007/s10570005-7136-2

35 A. G. Cunha, C. S. R. Freire, A. J. D. Silvestre, C. P. Neto, A. Gandini et al., J. Colloid Interface Sci., 316, $360 \quad$ (2007), https://doi.org/10.1016/j.jcis.2007.09.002

36 A. G. Cunha, C. S. R. Freire, A. J. D. Silvestre, C. P. Neto and A. Gandini, J. Colloid Interface Sci., 301, 333 (2006), https://doi.org/10.1016/j.jcis.2006.04.078

37 D. Nyström, J. Lindqvist, E. Östmark, A. Hult and E. Malmström, Chem. Commun., 3594 (2006), https://doi.org/10.1039/B607411A

38 A. G. Cunha, C. S. R. Freire, A. J. D. Silvestre, C. P. Neto, A. Gandini et al., Biomacromolecules, 8, 1347 (2007), https://doi.org/10.1021/bm0700136

39 A. G. Cunha, C. S. R. Freire, A. J. D. Silvestre, C. P. Neto, A. Gandini et al., Langmuir, 23, 10801 (2007), https://doi.org/10.1021/la7017192

40 A. G. Cunha and A. Gandin, Cellulose, 17, 875 (2010), https://doi.org/10.1007/s10570-010-9434-6

41 N. Lin, J. Tang and A. Dufresne (Eds.), "Advanced Functional Materials from Nanopolysaccharides", Springer, 2019, https://doi.org/10.1007/978-981-15-0913-1_9

${ }^{42}$ S. Zhang, W. Li, W. Wang, S. Wang and C.
Qin, Appl. Surf. Sci., 497, $143 \quad$ (2019), https://doi.org/10.1016/j.apsusc.2019.143-816

43 Y. Teng, Y. Wang, B. Shi and Y. Chen, Prog. Org. Coatings, 147, $105877 \quad$ (2020), https://doi.org/10.1016/j.porgcoat.2020.105877

44 Y. Teng, Y. Wang, B. Shi, X. Li and Y. Chen, Polym. Test., 91, $106810 \quad$ (2020), https://doi.org/10.1016/j.polymertesting.2020.1068 10

45 J. Zhou, X. Wang, Y. Li, H. Li and K. Lu, Cellulose, 27, $6617 \quad$ (2020), https://doi.org/10.1007/s10570-020-03227-1

46 A. El Idrissi, S. El Barkany, H. Amhamdi and A. K. Maaroufi, J. Appl. Polym. Sci., 128, 537 (2013), https://doi.org/10.1002/app.37500

${ }^{47}$ P. Jandura, B. V. Kokta and B. Riedl, J. Appl. $\begin{array}{llll}\text { Polym. } & \text { Sci., } & \mathbf{7 8}, & 1354\end{array}$ https://doi.org/10.1002/1097-

4628(20001114)78:7<1354::AID-

APP60>3.0.CO;2-V

48 A. Ben Mabrouk, H. Kaddami, S. Boufi, F. Erchiqui and A. Dufresne, Cellulose, 19, 843 (2012), https://doi.org/10.1007/s10570-012-9662-z

49 F. Z. Khan, M. Shiotsuki, Y. Nishio and T. Masuda, J. Membrane Sci., 312, 207 (2008), https://doi.org/10.1016/j.memsci.2007.12.068

50 S. Doyle and R. A. Pethrick, J. Appl. Polym. Sci., 33, $\quad 95$ (1987), https://doi.org/10.1002/app.1987.070330109

51 A. Calmon-Decriaud, V. Bellon-Maurel and F. Silvestre, Adv. Polym. Sci., 135, 207 (1998), https://doi.org/10.1007/3-540-69191-X_3

52 A. Krzan, S. Hemjinda, S. Miertus, A. Corti and E. Chiellini, Polym. Degrad. Stab., 91, 2819 (2006),

https://doi.org/10.1016/j.polymdegradstab.2006.04. 034

${ }_{53}$ Suhas, V. K. Gupta, P. J. M. Carrott, R. Singh, M. Chaudhary et al., Bioresour. Technol., 216, 1066 (2016), https://doi.org/10.1016/j.biortech.2016.05.106

54 M. N. Belgacem and A. Gandini, "Monomers, Polymers and Composites from Renewable Resources", Elsevier, first ed., 2008, https://doi.org/10.1023/A:1004666701711

55 H. S. Barud, A. M. de Araújo Júnior, D. B. Santos, R. M. N. de Assunção, C. S. Meireles et al., Thermochim. Acta, 471, 61 (2008), https://doi.org/10.1016/j.tca.2008.02.009

56 F. E. Tabaght, A. El Idrissi, M. Aqil, A. Benahemad, S. El Barkany et al., Cellulose Chem. Technol., $\quad 54, \quad 207 \quad$ (2020), https://doi.org/10.35812/CelluloseChemTechnol.20 20.54.23

57 C. Yin and X. Shen, Eur. Polym. J., 43, 2111 (2007),

https://doi.org/10.1016/j.eurpolymj.2007.01.041

$58 \mathrm{~W} . \mathrm{Hu}, \mathrm{S}$. Chen, Q. Xu and H. Wang, Carbohyd. Polym., 83, $1575 \quad$ (2011), https://doi.org/10.1016/j.carbpol.2010.10.016 


\section{FATIMA EZAHRA TABAGHT et al.}

59 G. R. Filho, S. F. da Cruz, D. Pasquini, D. A. Cerqueira, V. de S. Prado et al., J. Membrane Sci., 177, 225 (2000), https://doi.org/10.1016/S03767388(00)00469-5

60 A. El Idrissi, S. El Barkany, H. Amhamdi and A. K. Maaroufi, J. Appl. Polym. Sci., 127, 3633 (2013), https://doi.org/10.1002/app.37982

61 M. Van Der Zee, in "Biodegradable Polymers: Synthesis, Characterization and Applications", edited by A. Lendlein and A. Sisson, first ed., 2011, p.

263, https://doi.org/10.1002/9783527635818.ch11

62 C. M. Buchanan, R. M. Gardner and R. Komarek, J. Appl. Polym. Sci., 47, 1709 (1993), https://doi.org/10.1002/app.1993.070471001

63 P. Biely, Biotechnol. Adv., 30, 1575 (2012), https://doi.org/10.1016/j.biotechadv.2012.04.010

64 N. Jiang, L. Zhao and Z. Gan, Polym. Degrad. Stab., 95, 1045 (2010), https://doi.org/10.1016/j.polymdegradstab.2010.03. 004 